\title{
Hypothalamic Expression of a Novel Gene Product, VGF: Immunocytochemical Analysis
}

\author{
A. N. van den Pol, ${ }^{1}$ C. Decavel, ${ }^{1}$ A. Levi, ${ }^{2}$ and B. Paterson ${ }^{2}$ \\ ${ }^{1}$ Section of Neurosurgery, Yale Medical School, New Haven, Connecticut 06510, and 'Laboratory of Biochemistry, NCl, \\ $\mathrm{NIH}$, Bethesda, Maryland 20892.
}

VGF is the designation for a new 712 amino acid protein, regulated by nerve growth factor (NGF) in PC12 cells, that has not been previously described in the CNS. Northern blot analysis with a nick-translated VGF cDNA probe revealed a single band of mRNA in the brain with a molecular weight identical to that found in PC12 cells. The current paper presents a series of immunocytochemical studies of VGF expression with a focus on the hypothalamus. Two different antisera were raised against nonoverlapping amino acid sequences of a bacterial-expressed protein from the VGF gene cloned from PC12 cells. VGF immunoreactivity is strongly expressed in the rat suprachiasmatic nucleus (SCN), particularly in the dorsomedial part of the nucleus. The administration of colchicine to block axonal transport facilitates detection of the VGF immunoreactivity also in the ventrolateral suprachiasmatic nucleus. This protein appears to be the first one of limited neuronal distribution which is found in both dorsomedial SCN and ventrolateral SCN. Immunostaining of serial $1 \mu \mathrm{m}$ SCN sections reveals co-localization of VGF in cells which also contain vasopressin or vasoactive intestinal polypeptide. Weaker immunoreactivity is also found in the magnocellular paraventricular and supraoptic nuclei, where the VGF immunoreactivity co-localizes with oxytocin or vasopressin. Mutant Brattleboro rats which do not express vasopressin showed strong VGF immunoreactivity both in the dorsomedial SCN and in cells of the magnocellular neuronal systems, including cells which normally express vasopressin. When axonal transport of the protein is blocked by colchicine, VGF-immunoreactive cells in the hypothalamic arcuate, parvocellular paraventricular, and tuberomammillary nuclei can also be detected, in addition to weakly immunoreactive scattered cells in the hippocampus, amygdala, thalamus, and cortex.

VGF immunoreactivity is strong in the axonal projections of SCN and weak in the axons of the paraventricular and supraoptic nuclei. With ultrastructural studies, VGF immunoreactivity is found in presynaptic boutons in the SCN and in axons in the neurohypophysis. Weak axonal staining is

Received Dec. 6, 1988; revised Mar. 29, 1989; accepted Apr. 19, 1989.

We thank Ms. A. Schneider for technical assistance, and Drs. F. Gage, E. Johnson and $\mathrm{E}$. Shooter for nerve growth factor receptor antibody and suggestions related to it, and Drs. U. di Porzio, R. Vogt, and M. Bennett for useful discussion. Support was provided by NIH NS 10174 and NS 16296, and funds from the American Parkinson Disease Association.

Correspondence should be addressed to Anthony N. van den Pol, Ph.D., Section of Neurosurgery, Yale University School of Medicine, 333 Cedar Street, New Haven, CT 06510.

Copyright (C) 1989 Society for Neuroscience $0270-6474 / 89 / 124122-16 \$ 02.00 / 0$ present in some regions of the hypothalamus and in the external and internal zones of the median eminence. Immunoreactivity is absent from the intermediate lobe of the hypophysis.

In neonatal rats strong VGF immunoreactivity is found throughout the SCN at postnatal day 4 but not in the adjacent hypothalamus. VGF immunoreactivity is also seen in other areas of the brain in neonatal rats, including the lateral geniculate nucleus; while the staining in the dorsal lateral geniculate disappears in the adult, that in the intergeniculate leaflet, a visual center which projects to the SCN, remains.

Because VGF is dramatically increased by nerve growth factor via nerve growth factor receptors (NGF-R) in PC12 cells, we examined the hypothalamus for NGF-R. Strong immunoreactivity was found in the ventrolateral SCN, In the same region which receives axonal input from the retina and intergeniculate leaflet. No cellular co-localization of VGF and NGF-R immunoreactivity was found in the hypothalamus. These results suggest that the VGF expression in some cells may be regulated by NGF but may not require NGF for expression in the adult CNS.

The sequenced VGF gene shows no striking homology to any other protein. However, given the strong expression of VGF in the SCN, a putative biological clock in mammals, it is of speculative interest that a modest similarity in amino acid sequence exists with the Drosophila biological rhythm protein per.

This is the first study reporting VGF immunoreactivity in the CNS, where it appears to be selectively expressed in a limited number of neuronal systems, with the strongest immunostaining in the hypothalamus. Antisera were generated against proteins made by expression of the VGF mRNA in bacteria. The present study focuses on VGF protein in the hypothalamus, particularly the suprachiasmatic nucleus (SCN) and in the nearby magnocellular paraventricular (PVN) and supraoptic nuclei (SON), as described in a preliminary report (van den Pol et al., 1988).

The SCN has been suggested as an important circadian oscillator in the mammalian brain. That it may drive physiological, behavioral, and endocrine rhythms has been suggested by a variety of experiments, including studies using lesions (Moore and Eichler, 1972; Stephan and Zucker, 1972; van den Pol and Powley, 1979), electrophysiology on the nucleus isolated from afferent modulation (Inouye and Kawamura, 1979; Groos and Hendriks, 1982), and metabolic studies with 2-deoxyglucose and protein synthesis (Schwartz and Gainer, 1977; van den Pol, 1981). The magnocellular neurons of the PVN and SON have axons terminating in the neurohypophysis which release the 


\begin{tabular}{|c|c|c|c|c|c|c|c|c|c|c|}
\hline $\begin{array}{r}0 \\
50 \\
100 \\
150\end{array}$ & $\begin{array}{l}5 \\
\text { MKTFT } \\
\text { RPKDD } \\
\text { VPAGS } \\
\text { PEADD } \\
\text { ESPGP }\end{array}$ & $\begin{array}{l}10 \\
\text { LPRSV } \\
\text { SVPEV } \\
\text { QQGTP } \\
\text { AQKSW } \\
\text { DAVGA }\end{array}$ & $\begin{array}{l}15 \\
\text { LFCFL } \\
\text { RAARN } \\
\text { EEAAE } \\
\text { RHSIL } \\
\text { LPGES }\end{array}$ & $\begin{array}{l}20 \\
\text { ILIRG } \\
\text { SEPQD } \\
\text { ALLTE } \\
\text { AQELR } \\
\text { SRRAS }\end{array}$ & $\begin{array}{r}25 \\
\text { LGAAP } \\
\text { QGELF } \\
\text { SVRSQ } \\
\text { DFSPS } \\
\text { PERAP }\end{array}$ & $\begin{array}{r}30 \\
\text { PGRSD } \\
\text { QGVDP } \\
\text { THSLP } \\
\text { NAKRQ } \\
\text { LPPSV }\end{array}$ & $\begin{array}{l}35 \\
\text { VYPPP } \\
\text { RALAA } \\
\text { ASEIQ } \\
\text { QETAA } \\
\text { PSQFQ }\end{array}$ & $\begin{array}{l}40 \\
\text { LGSEH } \\
\text { VLLQA } \\
\text { ASAVA } \\
\text { AETET } \\
\text { ARMSE }\end{array}$ & $\begin{array}{l}45 \\
\text { NGQVA } \\
\text { LDRPA } \\
\text { PPRPQ } \\
\text { RTHTL } \\
\text { NVPLP }\end{array}$ & $\begin{array}{r}50 \\
\text { EDAVS } \\
\text { SPPPA } \\
\text { TQDND } \\
\text { TRVNL } \\
\text { ETHQF }\end{array}$ \\
\hline $\begin{array}{l}00 \\
50 \\
00\end{array}$ & $\begin{array}{l}\text { GEGVS } \\
\text { STRVS } \\
\text { AGCRR } \\
\text { RRGGG } \\
\text { IELST }\end{array}$ & $\begin{array}{l}\text { SPKTH } \\
\text { SGRGR } \\
\text { RSKSG } \\
\text { REAGA } \\
\text { KLHLP }\end{array}$ & $\begin{array}{l}\text { LGETF } \\
\text { EEAGG } \\
\text { EREGG } \\
\text { EDNAP } \\
\text { ADDVV }\end{array}$ & $\begin{array}{l}\text { DTLIQ } \\
\text { GTRQA } \\
\text { GGGRR } \\
\text { GGAPG } \\
\text { SIIEE }\end{array}$ & $\begin{array}{l}\text { ALPKS } \\
\text { AAQEE } \\
\text { RDAVV } \\
\text { HRRKD } \\
\text { MEEKR }\end{array}$ & $\begin{array}{l}\text { KCPLP } \\
\text { RLADL } \\
\text { GGRGG } \\
\text { AEGTE } \\
\text { KRKKN }\end{array}$ & $\begin{array}{l}\text { QVASA } \\
\text { ASDLL } \\
\text { EEIET } \\
\text { EGGEE } \\
\text { APPEP }\end{array}$ & $\begin{array}{l}\text { RGLIP } \\
\text { LQVLL } \\
\text { QASEQ } \\
\text { DDDDE } \\
\text { VPPPQ }\end{array}$ & $\begin{array}{l}\text { GRFRG } \\
\text { QAART } \\
\text { EREAA } \\
\text { EMDPQ } \\
\text { GCPSP }\end{array}$ & $\begin{array}{l}\text { RRA } \\
\text { AIS } \\
\text { ERA } \\
\text { TID } \\
\text { DPC }\end{array}$ \\
\hline $\begin{array}{l}00 \\
50 \\
00\end{array}$ & $\begin{array}{l}\text { PAAPT } \\
\text { ARILP } \\
\text { EHCCC } \\
\text { QGPAR }\end{array}$ & $\begin{array}{l}\text { SRPAR } \\
\text { PPSLP } \\
\text { TARDP } \\
\text { FCQDR }\end{array}$ & $\begin{array}{l}\text { DELPD } \\
\text { SRVAT } \\
\text { PLRAR } \\
\text { PVRLL }\end{array}$ & $\begin{array}{l}\text { WNEVL } \\
\text { CAPPS } \\
\text { SQLRA } \\
\text { WGLDP }\end{array}$ & $\begin{array}{l}\text { PPWDR } \\
\text { RSGAQ } \\
\text { PPRPP } \\
\text { GASPG }\end{array}$ & $\begin{array}{l}\text { EEDEV } \\
\text { ARRAQ } \\
\text { PCRSS } \\
\text { GCVVC }\end{array}$ & $\begin{array}{l}\text { FPPGP } \\
\text { EEADA } \\
\text { SLSVF } \\
\text { ASPLT }\end{array}$ & $\begin{array}{l}\text { YHPFP } \\
\text { EERRL } \\
\text { ACAPA } \\
\text { PPLPP }\end{array}$ & $\begin{array}{l}\text { NYIRP } \\
\text { QEQEE } \\
\text { RPRLP } \\
\text { GASSH }\end{array}$ & $\begin{array}{l}\text { RTI } \\
\text { LEN } \\
\text { PGP } \\
\text { LVS }\end{array}$ \\
\hline
\end{tabular}

Figure 1. Deduced amino acid sequence of the VGF protein. While no strong similarities were found in comparing the VGF sequence to several thousand other proteins in the NBRF sequence bank, one of the strongest similarities was with the per clock protein of Drosophila. This was $38 \%$, allowing substitution of amino acids. However, computer randomization of the VGF sequence, followed by comparison with per, still showed a $30 \%$ similarity, suggesting that part of the similarity was due to composition of amino acids rather than the more important sequence of amino acids. neurohormones oxytocin and vasopressin into the vascular system and mediate a number of endocrinological events.

Nerve growth factor (NGF) is required for the maturation and maintenance of sympathetic and sensory neurons in the PNS (Levi-Montalcini and Angeletti, 1968). In the PC12 cell line, derived from adrenal medullary pheochromacytoma, addition of NGF elicits the growth of long-branched neurites (Greene and Tischler, 1976). Part of the neuronal response to NGF appears to be at the level of induction of messenger RNA (Burstein and Greene, 1978), and several studies have examined the influence of NGF on messenger RNA in responsive cells by screening for novel or induced mRNA (Anderson and Axel, 1985; Levi et al., 1985; Leonard et al., 1987). The present paper focuses on one unique protein whose expression is greatly induced by NGF: when NGF was given to the adrenal chromaffin PC12 cell line, within $5 \mathrm{hr}$ a 50 -fold increase in a novel messenger RNA, called VGF, was found and the gene isolated with the use of a cDNA library of about 5000 clones (Levi et al., 1985). The VGF gene sequence appears to be a unique one and bears no significant similarity to sequences available in the $\mathrm{Na}$ tional Sequence Data Bank (1988). Given the role of the SCN in circadian rhythms, it is of some speculative interest here that, allowing substitution of related amino acids, the amino acid sequence of VGF deduced from the cDNA sequence shows a small similarity with the circadian clock protein of Drosophila (Jackson et al., 1986; Citri et al., 1987).

Recent evidence finding immunostaining of NGF receptors (NGF-Rs; Hefti et al., 1986; Batchelor et al., 1987; Yan and Johnson, 1988), binding of radiolabeled NGF (Raivich and Kreutzberg, 1987), messenger RNA coding for NGF (AyerLeLievre et al., 1988), and physiological effects of NGF in the CNS (Honegger and Lenoir, 1982; Gnahn et al., 1983; Williams et al., 1986; Gage et al., 1988) raises the possibility that NGF may participate in development and maintenance of certain neurons in the CNS. One of the questions asked in the present study is whether NGF-R and VGF immunoreactivity are in the same cells, a necessary prerequisite if VGF mediates the physiological effects of NGF.

\section{Materials and Methods}

Antisera. The amino acid sequence of the VGF protein (Fig. 1) was deduced from the complete cDNA sequence of the VGF gene (Levi et al., 1985). Northern blots of total RNA run on a formaldehyde gel from NGF-induced and noninduced PC12 cells and from brain were examined with radiolabeled VGF cDNA to determine the identity and level of expression of the VGF mRNA in brain using methods described in detail elsewhere (Levi et al., 1985).
Two different and nonoverlapping segments of the VGF open reading frame were fused into the $\beta$-galactosidase ( $\beta$-gal) $E$. coli bacterial gene. One segment included the amino acid sequence from 80 to 340 , and the other the amino acid sequence from 443 to 588 . The bacteria then made the translation product of the cDNA gene fusion. After gel purification, the 2 protein fragments were injected into different rabbits to produce antisera. Antisera made against these 2 protein fragments are designated as VGF80 and VGF443, respectively. The designation of "VGF" for the protein is based on the alphabetical code used during the isolation of this particular cDNA clone and has no mnemonic representation. More details of the cloning and expression of these vectors will be presented elsewhere (A. Levi et al., unpublished observations).

Immunostaining procedure. Twenty-five albino or pigmented male and female adult rats were used for the immunostaining experiments described here. Animals were given an overdose of Nembutal anesthetic and perfused through the heart with physiological saline followed by aldehyde fixative. The fixative contained $4 \%$ freshly made paraformaldehyde with up to $0.1 \%$ glutaraldehyde. Higher concentrations of glutaraldehyde inhibited the immunostaining, even if tissue was subsequently treated with sodium borohydride.

Coronal sections, 30-50 $\mu \mathrm{m}$, were cut on a Vibratome, washed in phosphate buffer, treated with $1 \%$ sodium borohydride for $30 \mathrm{~min}$, and incubated in primary antiserum at a dilution of 1:1000 to 1:4000. Some sections were then stained with the PAP method of Sternberger (1986), using a secondary link antiserum of swine anti-rabbit $\operatorname{IgG}(1: 1000)$ from Dako, and peroxidase-antiperoxidase (1:1000) also from Dako. Other sections were stained with a biotinylated secondary antiserum and the ABC complex of Hsu et al. (1981) from Vector Labs. The diaminobenzidine (DAB) reaction was sometimes intensified by the addition of nickel salt. To further increase visibility of DAB reaction product, immunostained cells and processes were sometimes intensified with silver (Gallyas and Merchenthaler, 1988). Some sections were stained with silver-intensified $1 \mathrm{~nm}$ colloidal gold (Janssen) adsorbed to secondary goat anti-rabbit serum (van den Pol, 1985). Additional brains were embedded in paraffin, and $7 \mu \mathrm{m}$ sections were cut, put on gelatin-coated slides, and stained with the PAP or ABC methods.

To compare the distribution of VGF with other known peptides in the SCN, PVN, and SON, immunostaining for additional peptides was compared with that seen with VGF. These included vasopressin, oxytocin, neurophysin (gift of Dr. Michael Sofroniew or purchase from Immuno Nuclear Corp.), vasoactive intestinal polypeptide (Immuno Nuclear Corp.), and gastrin-releasing peptide (Peninsula). Details of the peptide antisera specificity and immunostaining procedures have been given elsewhere (Sofroniew and Weindl, 1978, 1980; van den Pol and Tsujimoto, 1985; van den Pol, 1986).

A monoclonal antibody against the NGF-R (gift from E. Johnson and E. Shooter; Chandler et al., 1984) was used to look for anatomical correlations with VGF immunoreactivity. Specificity and characterization of this antibody are discussed in detail elsewhere (Chandler et al., 1984; Yan and Johnson, 1988).

Colchicine administration. Some rats were given an injection of colchicine $(30 \mathrm{mg} / \mathrm{kg}$ body weight) with a Hamilton microsyringe into the CSF of the lateral ventricle to block axonal transport. Thirty hours later, animals were given an overdose of anesthetic and perfused as described above. Thirty micron Vibratome sections or thin paraffin sections were cut from the brains of these rats. 
VGF RNA in Adult Brain

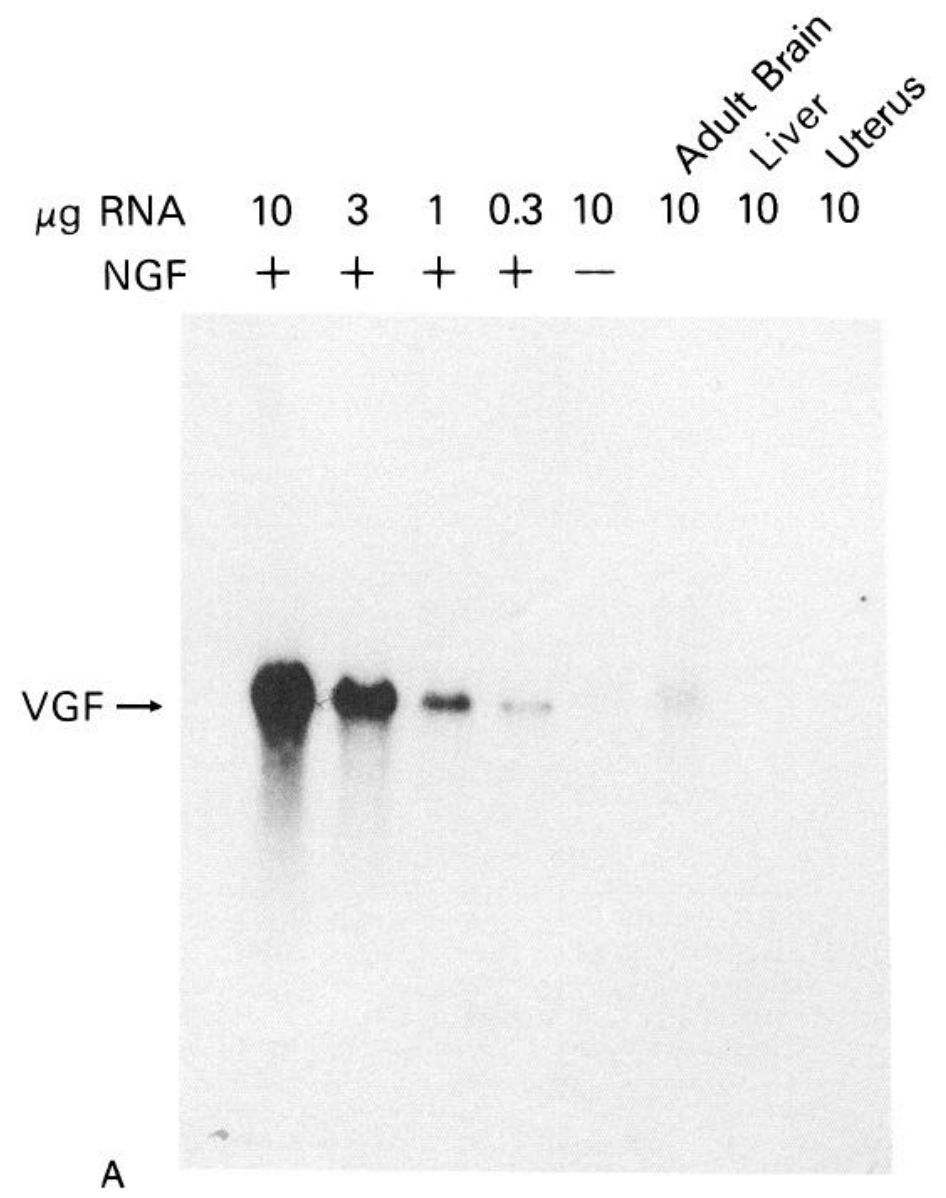

Abs to Lac Z Fusion

\section{Total PC 12 Protein}

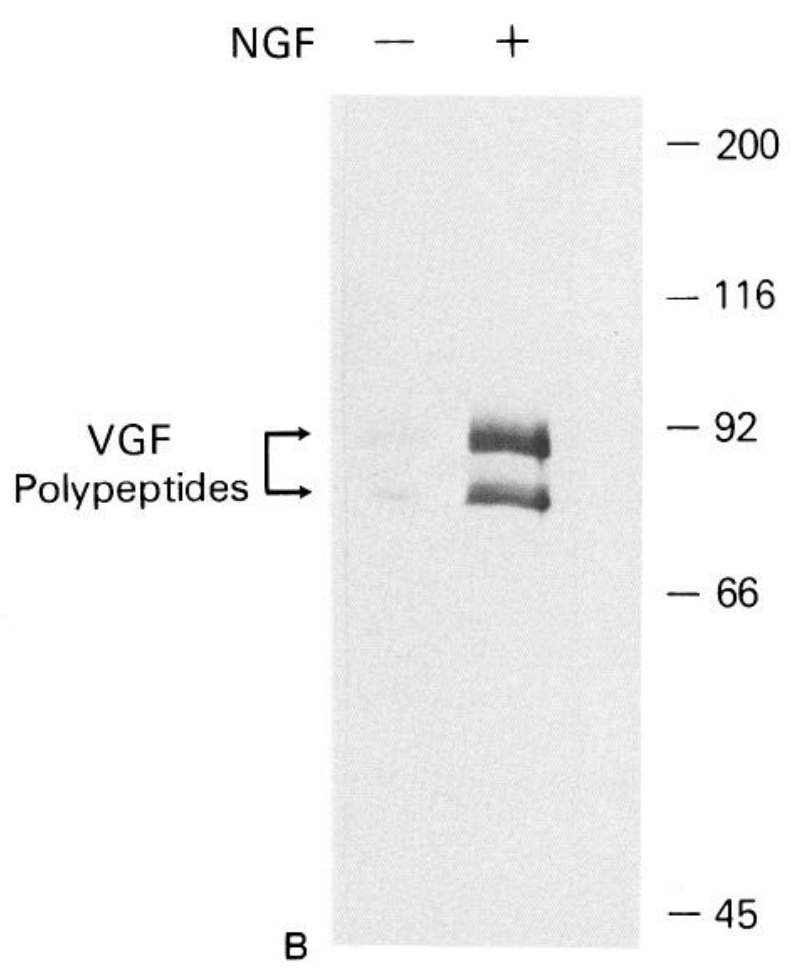

Figure 2. A, Northern blot from formaldehyde gel electrophoresis shows RNA from PC12 cells induced by $2.5 \mathrm{~s} \mathrm{NGF}$ (100 ng/ml), compared with noninduced PC12 cells, brain, liver, and uterus, detected with radiolabeled nick-translated VGF cDNA. To increase the probability of detecting VGF mRNA in organs containing only small amounts, RNA from brain, liver, and uterus was purified by poly $\mathrm{A}^{+}$selection. No VGF mRNA was found in liver or uterus, but it was detected in brain. $B$. Antibodies made against the gene product expressed by a fusion of the VGF gene to the Lac Z gene stains a doublet of proteins on a Western blot. The doublet is strongly expressed after NGF stimulation $(+)$ and weakly expressed in nonstimulated $(-)$ cells.

Brattleboro rats. In addition to normal pigmented and albino rats, 3 male Brattleboro rats which have a vasopressin gene defect (Schmale and Richter, 1984; Majzoub et al., 1987) and do not express immunostainable vasopressin or its associated neurophysin were used for immunostaining of the VGF protein.

Neonatal rats. To study the expression of the VGF protein in neonatal rats, 4-d-old rat brains were fixed and cut in $30 \mu \mathrm{m}$ sections. The morning of birth was considered day 0 .

Electron microscopy. Vibratome sections intended for electron microscopy were treated with $1 \%$ osmium tetroxide, $2.5 \%$ uranyl acetate, dehydrated through alcohol and acetone, and embedded in Araldite. Ultrathin sections were saved on mesh or Formvar-coated single-slot grids and viewed in a Philips 201 electron microscope.

Co-localization immunocytochemistry. To study what neuroactive substances might be co-localized in the same neurons that were immunoreactive for VGF, tissue from colchicine-treated rats was used. Paraffin sections, $1 \mu \mathrm{m}$, were cut on a Reichert ultramicrotome with glass knives. Serial adjacent semithin sections were stained for different antigens known to be present in the particular area of interest. Single cells were then identified and photographed, and immunoreactivity for different antigens was compared. Cells were not counterstained because Nissl stains often decrease the visibility of the light reaction product. Differential interference contrast imaging facilitated visualization of other landmarks around immunoreactive cells.

Immunostaining controls. As the VGF cDNA was constructed in series with the gene for $\beta$-gal, the proteins produced by the resultant
mRNA contain both the amino acid sequence for $\beta$-gal and for the respective partial sequence of VGF. Several control experiments were performed to ensure that the antisera did not bind to $\beta$-gal or some amino acid sequence with homology to $\beta$-gal in the brains used. Purified $\beta$-gal $(0.33 \mathrm{mg} / \mathrm{ml}$; Sigma) was incubated with antisera diluted 1:3000 overnight before antisera was used for immunostaining. Additionally, a crude bacterial homogenate of the K12 strain of $E$. coli containing $\beta$-gal and other bacterial proteins was mixed with the VGF antisera to further test the possibility of cross-reacting antisera. The concentration of soluble extract was $200 \mu \mathrm{g} / \mathrm{ml}$ of diluted antisera. A different antiserum (gift of Dr. Peter Tattersall) made against a $\beta$-gal fusion product to lambda cro (Cotmore and Tattersall, 1986), a bacteriophage gene unrelated to the VGF gene, was used to stain the same areas of brain where positive immunostaining was obtained with VGF antisera.

\section{Results}

To determine the relative amount of VGF mRNA in brain, we compared NGF induced and noninduced PC12 cells with brain. The mRNA found in brain had the same molecular weight as that in PC12 cells (Fig. 2A). Both antisera against the VGF translation product stained a doublet of proteins of roughly 90,000 and 75,000 Da, as shown in the Western blot probed with peroxidase-labeled antibodies (Fig. $2 B$ ). The lower-molec- 
ular-weight band is probably a posttranslational cleavage product of the larger molecule, based on pulse-chase experiments with radiolabeled proline and on the expression of 2. similarweight proteins in $E$. coli which were transfected with the complete VGF cDNA (Levi et al., unpublished observations). The amino acid sequence of the VGF protein, deduced from the gene sequence is shown in Figure 1. The protein contains 712 amino acids, a high percentage of proline (13\%), and a number of arginine-arginine and arginine-lysine pairs, possible sites of proteolytic cleavage for reduction of VGF protein to smaller peptides.

$S C N$. A large number of neural loci were examined, including the hypothalamus, thalamus, hippocampus, cortex, septum, striatum, mesencephalon, and spinal cord. The most intense immunoreactivity with antisera against both of the nonoverlapping amino acid sequences of the VGF protein was found in the hypothalamic SCN. The greatest concentration of immunoreactive cells was found in the middle and caudal part of the nucleus, where cells were located primarily in the dorsomedial region of the SCN (Fig. $3 A$ ). In the rostral part of the nucleus, a few immunoreactive cells were detected above the optic chiasm. Similar results were obtained in horizontal sections (Fig. $3 C$ ); immunoreactive cells were found primarily in the medial aspect of the dorsal part of the nucleus (Fig. 3, $A, B$ ), with the long axis of the perikaryon running parallel to the third ventricle.

In addition to stained perikarya (Fig. $3 B$ ), thin axons were seen both within the nucleus and leaving the nucleus, particularly in a dorsocaudal direction. High densities of immunoreactive axons were seen in the periventricular area throughout the hypothalamus, and particularly in dorsal regions in the area of the paraventricular nucleus. Immunoreactive axons were seen in the major projection areas of SCN (Watts et al., 1987), including the medial preoptic area, lateral hypothalamus, dorsomedial nucleus, ventral lateral septum, and bed nucleus of the stria terminalis. Both males and females showed positive immunoreactivity.

Magnocellular PVN and SON. Perikarya of the PVN and SON showed a weaker positive immunostaining than seen in the SCN. The intensity of the immunostaining reaction product at the cellular level appeared slightly different with the 2 antisera. At low concentrations, the VGF443 antiserum stained predominantly perikarya and occasional thick dendritic processes (Fig. $4 B$ ), while the VGF80 appeared to stain a higher number of isolated thick dendritic processes ventral to the SON (Fig. 4A) and within the lateral paraventricular nucleus in addition to perikarya. VGF immunoreactive neurons were found scattered throughout regions of the PVN rich in large cells (Fig. 4C).
As with cells of the SCN, some neurons of the PVN and SON stained strongly, and others weakly (Fig. 4, $A, B$ ). In $30-\mu \mathrm{m}$ thick sections, the intensity of staining appeared heterogeneous. To determine whether this cellular heterogeneity was due to antiserum penetration into thicker sections or to real differences in the amount of antigen, we examined thinner 7 and $1 \mu \mathrm{m}$ sections. A clear difference in staining intensity was seen in adjacent neurons examined at the level of each cell's nucleus. This was a reliable finding in that when serial $1 \mu \mathrm{m}$ sections of the same cells were examined, weakly stained cells were consistently weak and strongly stained cells were consistently stained intensely.

With peroxidase immunocytochemistry, the large neurosecretory axons of the PVN and SON which leave the respective nuclei and innervate the neurohypophysis were not detected. When an antiserum against neurophysin was substituted for VGF antisera, the large neurosecretory axons were readily identified. With VGF antisera, the neurohypophysis was immunoreactive, particularly in contrast to the absence of staining in the adjacent intermediate lobe of the pituitary (see Fig. $6 F$ ) from the same section. Since the finding of immunoreactivity in the neurohypophysis seemed incompatible with the absence of the antigen from the axons arising in the magnocellular neurons and terminating in the neurohypophysis, we also tried silver intensification of the peroxidase reaction product, which is more sensitive than peroxidase alone and may facilitate detection of smaller levels of endogenous antigen. With silver immunostaining with VGF antisera, the large axons of the PVN were detectable leaving the nucleus and were also found in the region around the fornix where they occur before turning ventrally and proceeding to the neurohypophysis. Immunoreactivity suggestive of axonal expression was found in the superficial zone of the spinal cord, in the same region where oxytocin and vasopressin fibers from the PVN can be found (Swanson and McKellar, 1979), and in other regions of the cord.

Other hypothalamic areas. Immunoreactivity was also seen in some other neuronal perikarya in the hypothalamus. The large ncurons of the accessory magnocellular nuclei, roughly distributed in the hypothalamus between the paraventricular and ipsilateral SON, were labeled (Fig. $5 E$ ). Additionally, some of the parvocellular neurons in the medial areas of the PVN were stained. Also labeled were cells in the immediate retrochiasmatic region, as were a few cells of the arcuate nucleus (Fig. 5A).

Axonal transport block. When colchicine was infused into the lateral ventricle, a dramatic increase in the labeling of cell bodies in immunoreactive areas was apparent. The increase in labeling

\footnotetext{
Figure 3. VGF immunoreactivity in SCN. $A$, Strong VGF immunoreactivity is found in the dorsomedial SCN on both sides of the third ventricle in a coronal section. Scale bar, $140 \mu \mathrm{m}$. $B$, Higher magnification of dorsomedial SCN showing labeled cells (arrows) and fibers. Scale bar, $40 \mu \mathrm{m}$. $C$, Dense immunoreactivity is seen along the third ventricle (bottom) in this horizontal section of the SCN. Scale bar, $110 \mu \mathrm{m} . D$. No immunoreactivity is seen in control section stained with lambda cro- $\beta$-galactosidase $(\beta$-gal) antibodies. $3 V$, third ventricle. Scale bar, $125 \mu \mathrm{m}$. $E$, Positive staining is found with lambda cro- $\beta$-gal at border of anterior lateral hypothalamus $(L H)$. Scale bar, $50 \mu \mathrm{m}$.
}

Figure 4. Immunoreactivity of antisera against different sequences of VGF. $A$, The VGF80 sequence stains supraoptic neurons and dendrites particularly in the ventral lamina of the SON. Scale bar, $55 \mu \mathrm{m}$. $B$, VGF443 stains cells in the same area. Intensity of reaction product is heterogeneous in all areas where cells stain positive. $C$, Strong immunostaining of axons found running from the dorsocaudal SCN to PVN (arrows). Scale bar, $300 \mu \mathrm{m}$. $D-G$, Colchicine treatment. $D$, VGF immunoreactivity is found in many more cells after colchicine than in nontreated tissue. Immunoreactive neurons appear not only in the dorsomedial SCN but also in the ventrolateral SCN, and they are even found embedded in the optic chiasm. Scale bar, $120 \mu \mathrm{m} . E$ and $F$, The number of immunoreactive cells in the PVN and SON increases greatly after cochicine treatment. Scale bar, 110 $\mu \mathrm{m} . G$, Cells in the posterior SON are not easily seen in nontreated tissue but stain darkly after colchicine treatment. Scale bar, $90 \mu \mathrm{m}$. 

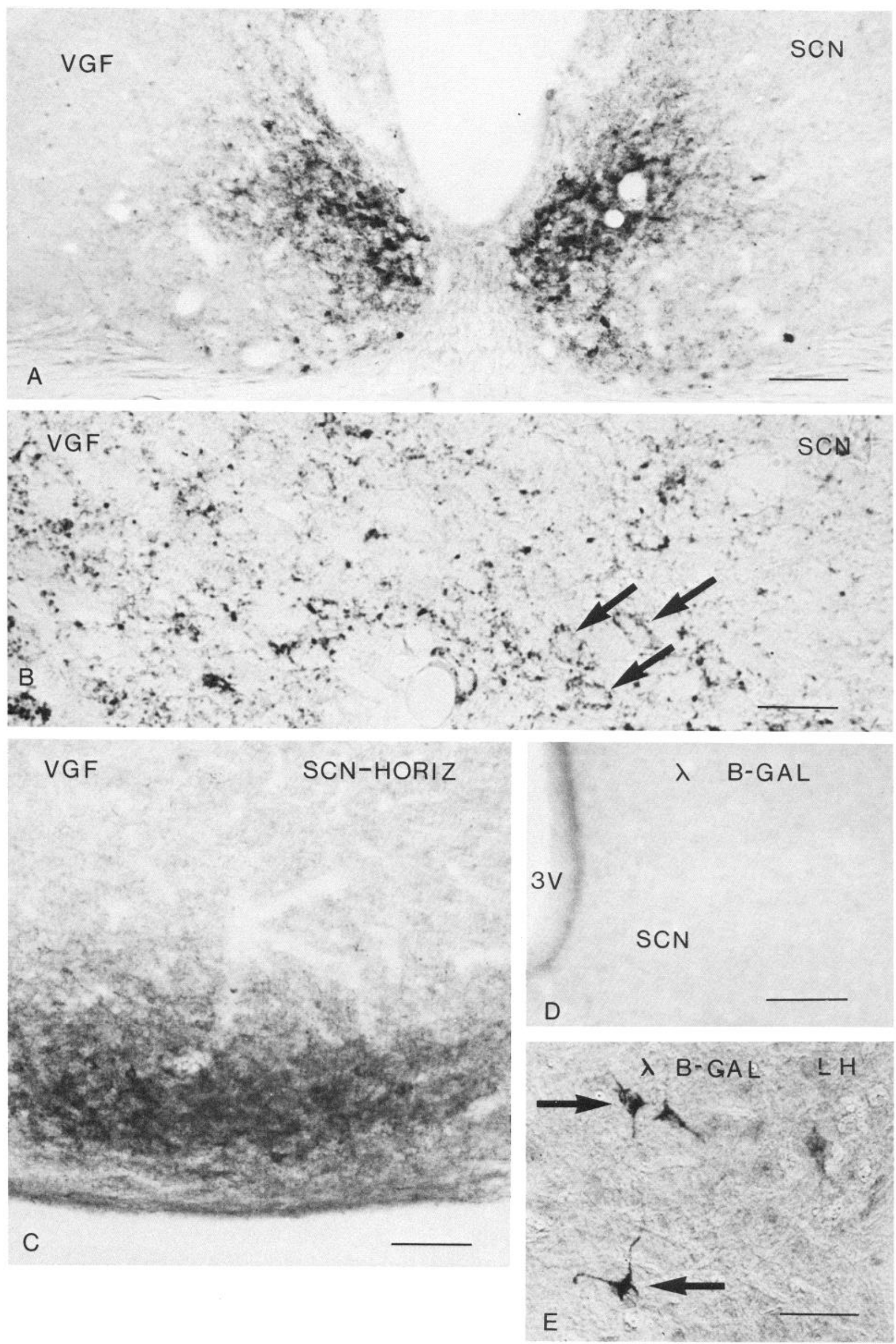


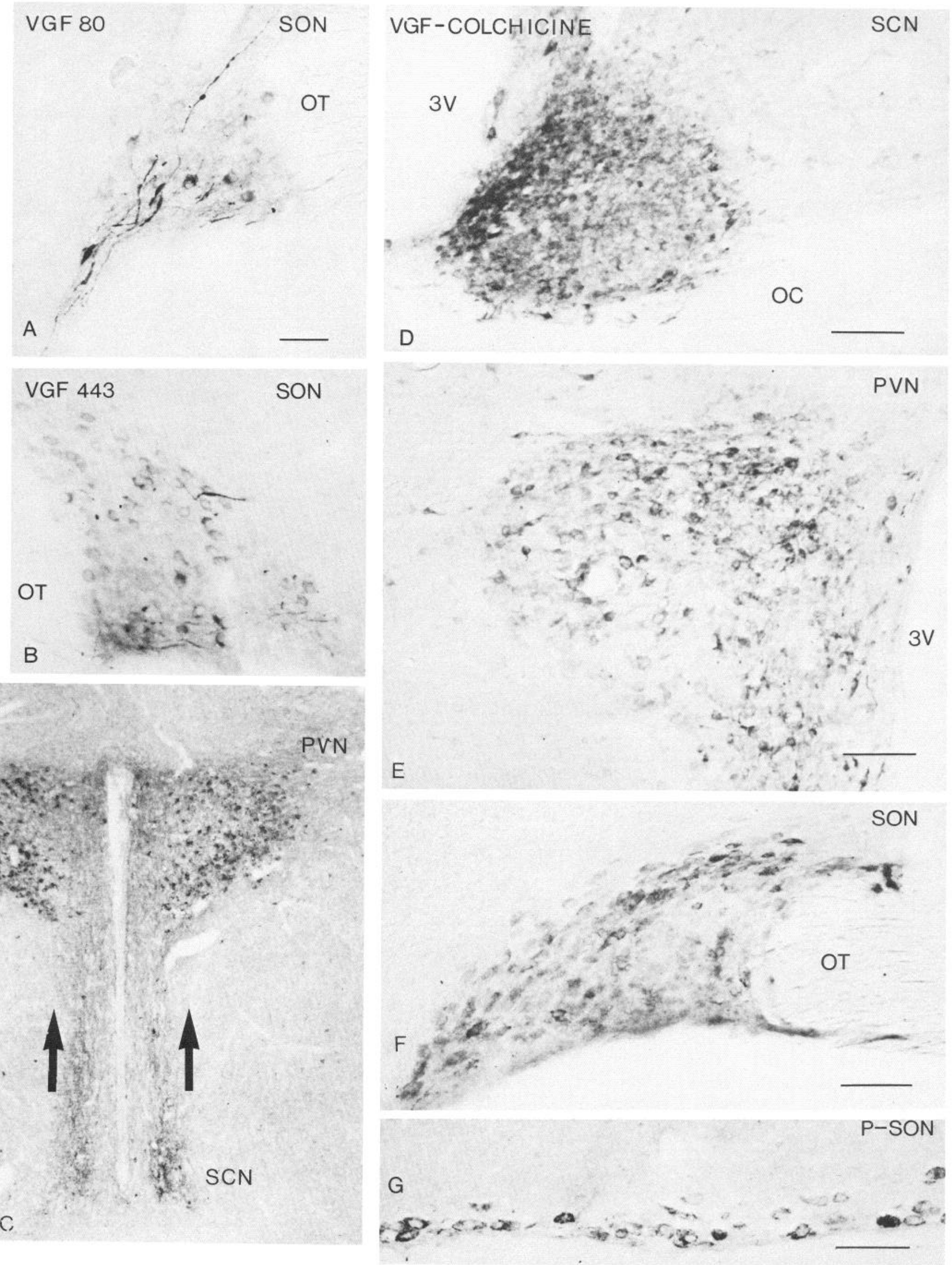


intensity tended to reduce the cellular heterogeneity of staining intensity found in non-colchicine-treated rats in the SCN, PVN, and SON.

VGF immunoreactive cell bodies were most apparent in the dorsomedial part of the SCN in untreated rats, but with colchicine treatment, immunoreactive cells were identified throughout the ventral SCN (Fig. 4D), often embedded in the dorsal aspect of the optic chiasm. In the PVN and SON, the number of immunoreactive neurons increased to the point that most magnocellular neurons (Fig. $5 B$ ) and some of the smaller neurons (Fig. $5 B$ ) in the medial PVN were labeled with each of the 2 antisera. The high proportion of immunoreactive magnocellular neurons was most clearly seen in thin paraffin sections (Fig. $5 B$ ) and was less obvious in thick Vibratome sections (Fig. $4, E, F)$. VGF immunoreactivity appeared in magnocellular regions of the SON and PVN where both oxytocin and vasopressin were found.

When axonal transport was blocked by colchicine administration, a striking increase in the number of immunoreactive cell bodies was found in the arcuate nucleus (Fig. 5, $A, C, D$ ), as well as in the caudal dorsomedial hypothalamus and in the tuberomammillary nucleus $(5, C, D)$, as defined by Ericson et al. (1987).

Although the intensity of immunostaining appeared strongest in the hypothalamus, immunoreactivity was also found in other restricted regions of the brain, including the thalamus, hippocampus, cortex, amygdala, bed nucleus of the stria terminalis, pallidum, medial preoptic area, and habenula. A diffuse immunoreactivity suggestive of axons was found in the substantia nigra, with the greatest concentration of labeling in the medial part of the pars reticulata and less in the lateral part. When colchicine was given to block axonal transport, a stronger immunoreactivity was found in neurons of all regions outside the hypothalamus where immunoreactivity was found in nontreated rats.

Hypothalamic axons. Axons were densely labeled in the area between the SCN and PVN (Fig. 4C). Immunoreactive axons were also seen in the arcuate nucleus and in the median eminence in both the external lamina and in the internal lamina (Fig. 6A). Small immunoreactive axons were prevalent in the dorsomedial hypothalamus but were found in smaller numbers in the ventromedial hypothalamus (Fig. $6 B$ ). In the periventricu- lar hypothalamus, axons were found which maintained boutons near selected unstained cells (Fig. 6C); some axons were very thin, while others were much thicker and intensely immunoreactive (Fig. $6 D$ ). Dorsal to the $\mathrm{SCN}$, large numbers of immunoreactive axons were detected (Fig. 6E).

Ultrastructural immunocytochemistry. VGF immunoreactivity was studied in the dorsomedial SCN after peroxidase immunostaining. Immunoreactivity was found in small neuronal cell bodies which contained organelle-poor cytoplasm (Fig. 7 A), similar to previous studies on the morphology of neurons in this area of the SCN (van den Pol, 1980). The detectable reaction product did not appear to be associated with any particular organelle, but rather was found distributed throughout the cytoplasm; nuclei were not labeled. Reaction product was found in high concentrations in axonal boutons making synaptic contact with other dendrites and perikarya (Fig. $7, C, D$ ). Immunoreactive boutons contained small clear vesicles and generally had some medium-size dense-core vesicles in them. Immunoreactivity was not found in glial cells. In the neural lobe of the pituitary, immunoreactivity was found in the large axons of magnocellular neurons which contained large neurosecretory granules (Fig. $7 B$ ) and in some smaller axons which contained dense-core granules, as well as smaller clear vesicles.

Rats with vasopressin gene defect. The hypothalami of Brattleboro rats were examined after immunostaining. As expected from previous papers, vasopressin cells in the dorsomedial SCN of homozygous Brattleboro rats could not be detected with antiserum against the vasopressin-neurophysin antigen (Fig. $8 B$ ) but could be detected in other normal nonhomozygous rats of the same age and Long-Evans strain (Fig. 8C). On the other hand, in the homozygous Brattleboro rat, VGF immunoreactivity was found in the dorsomedial SCN (Fig. $8 \mathrm{~A}$ ) and throughout the SON and PVN, including regions where high densities of vasopressin-containing cells would normally be found, such as in the ventral SON and the core of the lateral PVN, as defined by Armstrong et al. (1980), and also called the dorsolateral part of the posterior PVN according to Swanson and Sawchenko (1983). Positive immunostaining was found with both the VGF80 and the VGF443 antisera. No readily detectable differences were found in the general distribution of VGF when vasopressingene-deficient rats were compared with normal rats.

Co-localization. Serial $1 \mu \mathrm{m}$ paraffin sections were stained Figure 5. Colchicine treatment- hypothalamus. $A$, An increase in the number of immunoreactive cells is found in the ventrolateral area of the
arcuate nucleus $(V L-A R C)$. Scale bar, $40 \mu \mathrm{m}$. B, In paraffin sections of PVN, most of the large magnocellular neurons are labeled after colchicine
treatment. Additionally, some of the smaller parvocellular neurons in the medial PVN (right) are labeled. Scale bar, $45 \mu \mathrm{m}$. $C$, In the caudal
hypothalamus, labeled cells are found after colchicine treatment (bar, $200 \mu \mathrm{m})$, particularly in the tuberomammillary nucleus $(T M)$, and arcuate
nuclcus $(A R C)$ but not $(D)$ in the adjaccnt ventral premammillary arca $(V-P R E M A M)$. $3 V$, third ventriclc. Scale bar, $125 \mu \mathrm{m}$. $E$, Neurons in the
accessory magnocellular groups of cells are immunoreactive with VGF. Scale bar, $21 \mu \mathrm{m}$.

Figure 6. VGF immunoreactive axons. $A$, In the arcuate nucleus $(A R C)$ and adjacent median eminence (ME), immunoreactive axons (hollow arrows) are seen. A few weakly immunoreactive cells are seen in the arcuate nucleus (black arrows). Scale bar, $40 \mu \mathrm{m}$. $B$, The density of VGF immunoreactive axons is much greater in the dorsomedial hypothalamus $(D M H)$ than in the immediately adjacent ventromedial hypothalamus. Border between the 2 areas is indicated by arrows. Scale bar, $35 \mu \mathrm{m}$. C, Small axons in the periventricular area ventral to the PVN exhibit terminal boutons (hollow arrow) and appear to surround 2 cell bodies (black arrows). Scale bar, $30 \mu \mathrm{m}$. D. Within the periventricular area both thick (black arrow) and fine (hollow arrows) axons are found. Scale bar, $30 \mu \mathrm{m}$. E. Axons dorsal to the SCN often are found running from the SCN toward the PVN (direction of arrows). Scale bar, $30 \mu \mathrm{m} . F$, VGF in pituitary. Only the neural lobe is immunoreactive for VGF, while the intermediate and anterior lobes are not labeled. Scale bar, $60 \mu \mathrm{m}$.

Figure 7. VGF immunoreactivity ultrastructure. $A$, A neuron (N2) in the SCN contains VGF immunoreactivity as shown by the peroxidase reaction product. A second neuron $(N)$ does not show any reaction product. The long axis of these organelle-poor neurons is generally oriented in a rostrocaudal axis. Scale bar; $1.53 \mu \mathrm{m}$. $B$, Two large axon terminals in the neurohypophysis labeled with peroxidase are immunoreactive for VGF, while an adjacent axon (arrow) shows no immunoreactivity. Scale bar, $830 \mathrm{~nm}$. VGF-immunoreactive axonal bouton $(A X)$ makes synaptic contact (arrow) with a perikaryon $(P E R)(C$; scale bar, $450 \mathrm{~nm})$ or with a dendrite $(D E N)$ in the $\mathrm{SCN}(D$; scale bar, $500 \mathrm{~nm})$. $N U$, nucleus. 

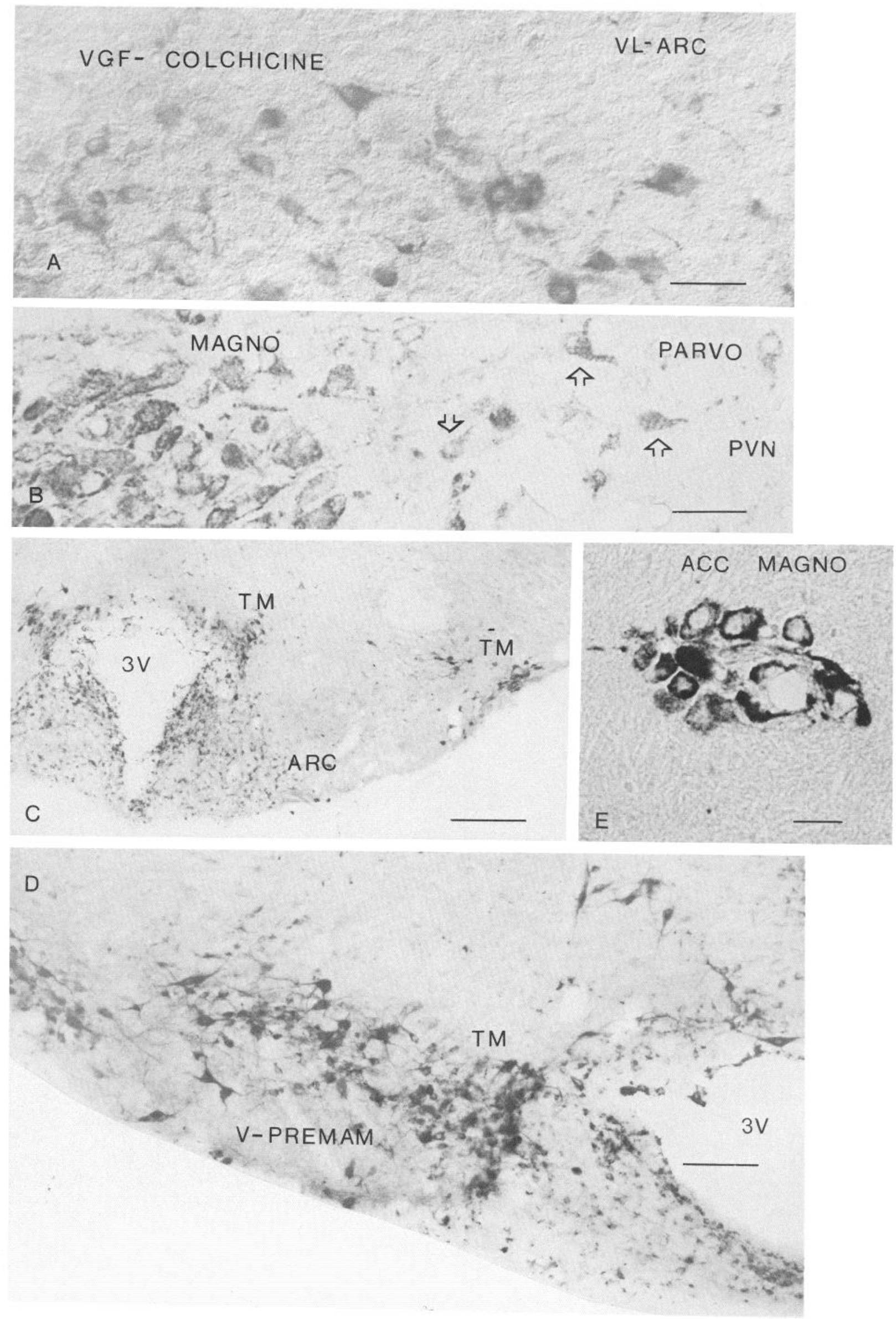

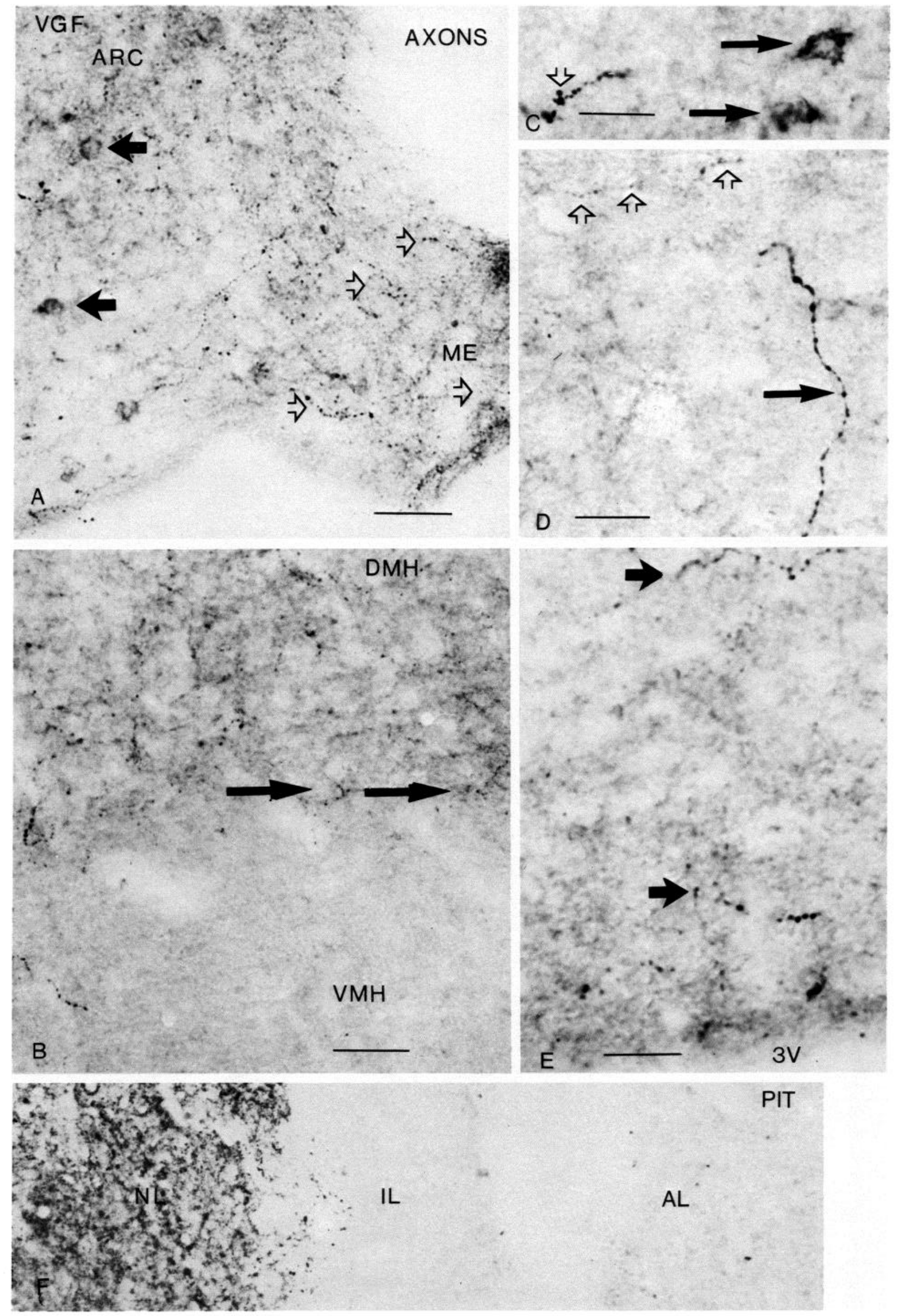

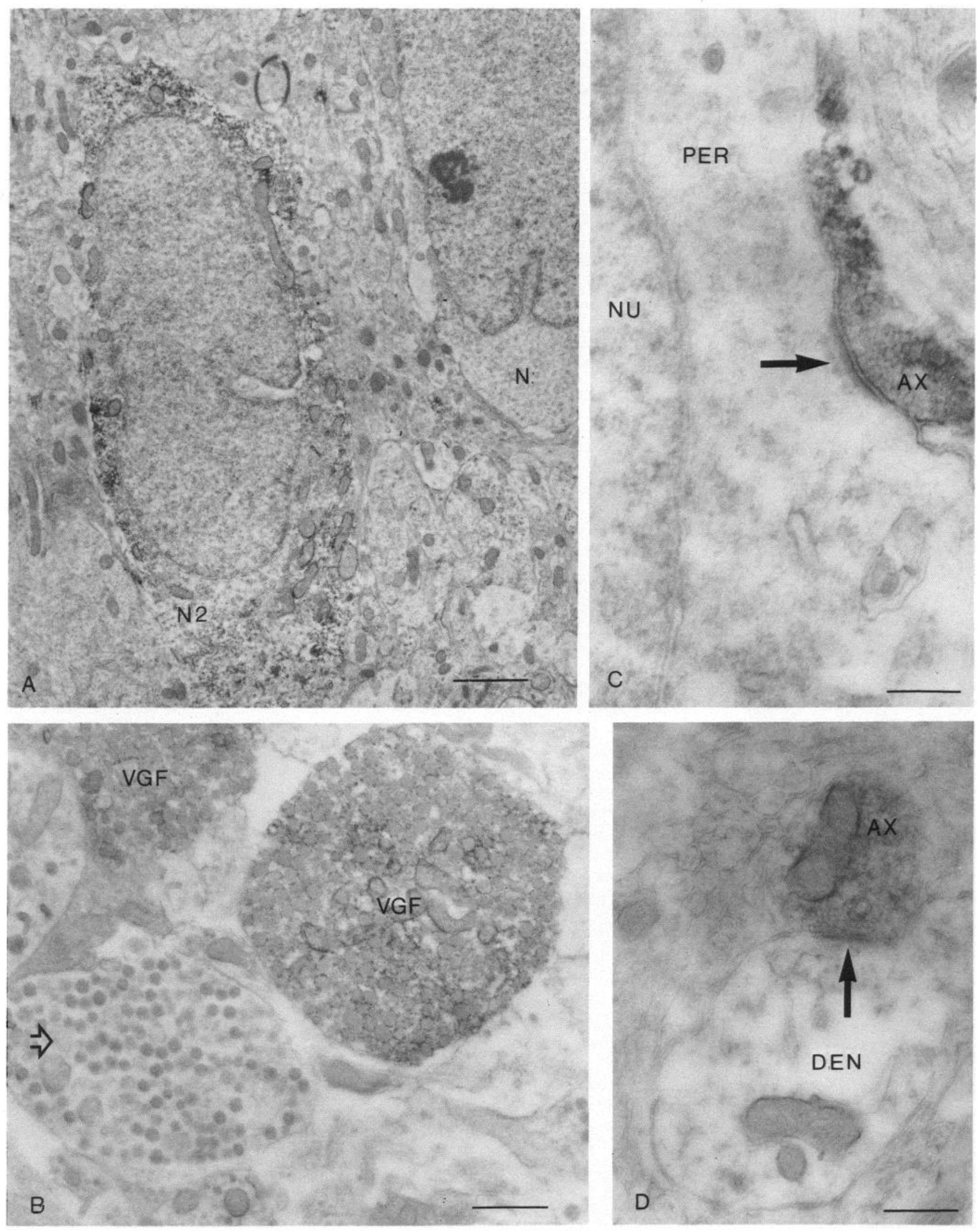


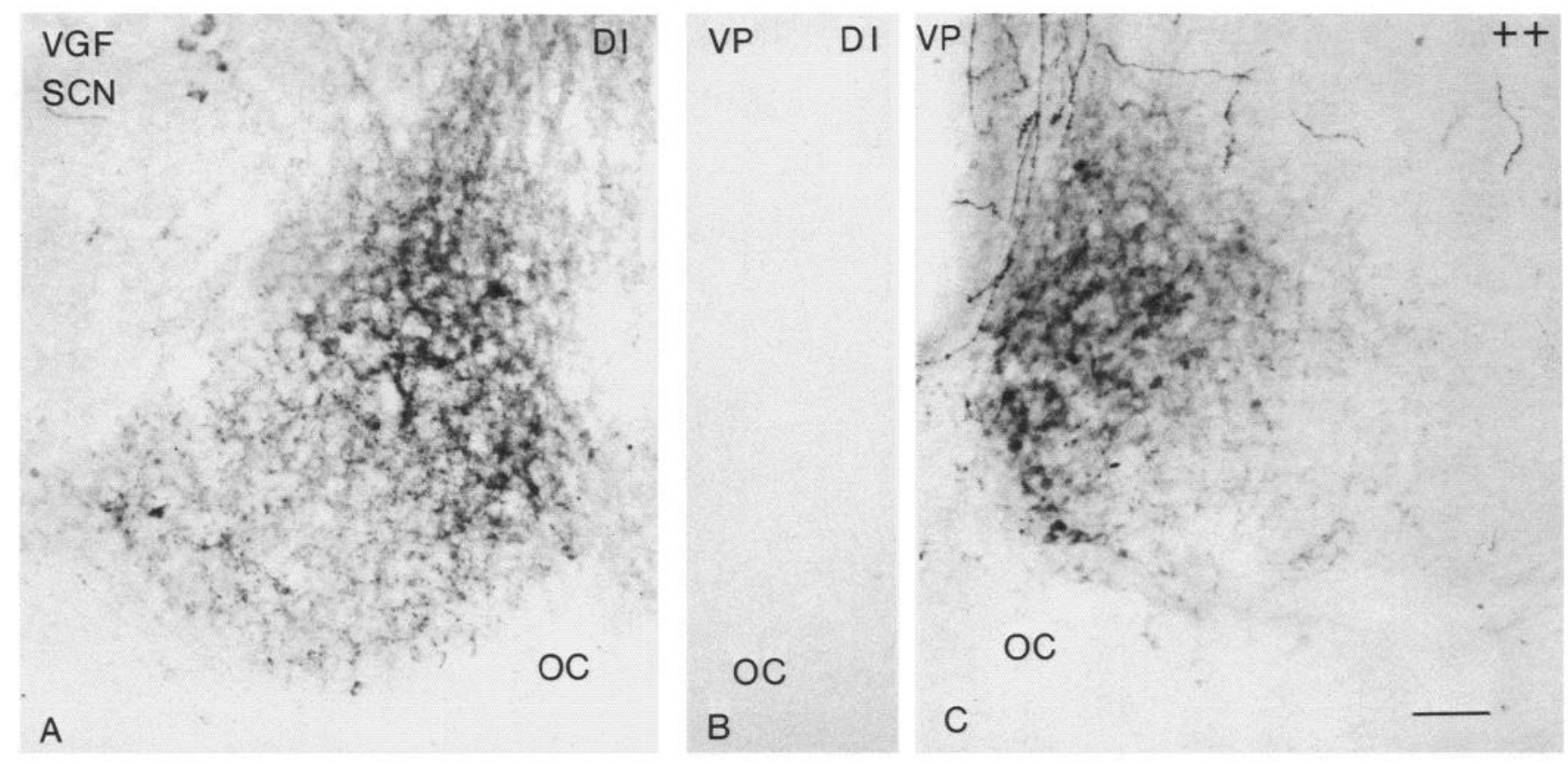

Figure 8. VGF in Brattleboro rat. A, Strong VGF immunoreactivity is seen in the dorsomedial SCN of a Brattleboro rat (DI, diabetes insipidus). $B$, In control sections of mutant rat, vasopressin-neurophysin $(V P)$ immunoreactivity is not seen in the SCN, as expected, but is seen in a normal $(++)$ rat of the same strain. Scale bar, $100 \mu \mathrm{m}$. $O C$, optic chiasm.

with different antisera, and co-localization of VGF and peptide immunoreactivity was studied. To increase immunoreactivity in cells expressing low levels of antigen, colchicine was used to block axonal transport. In the $\mathrm{SCN}$ as expected from the strong VGF immunoreactivity in the dorsomedial SCN, VGF co-localized with vasopressin (Fig. 9, $C, D$ ). In the ventrolateral $\mathrm{SCN}$, cells which were immunoreactive with VGF (Fig. $9 B$ ) also were immunoreactive for vasoactive intestinal polypeptide. In both sets of pairs, more cells were stained with VGF than with the peptide antisera. In the PVN and SON, VGF immunoreactivity was found in cells which were immunoreactive for both oxytocin or vasopressin (Fig. 9, $E-H$ ). In the SCN, PVN, and SON there appeared to be a positive correlation between staining intensity for VGF and the other antigen co-localized in the same cell.

$V G F$ expression in $S C N$ and other visual regions in developing rats. Strong immunoreactivity was found in the SCN of neonatal rats $4 \mathrm{~d}$ after birth (Fig. 10B). The staining pattern was noteworthy in that cells of both the dorsomedial and ventrolateral regions were immunoreactive, with the dorsomedial region expressing a stronger level of immunoreactivity. Immunoreactivity was also seen in magnocellular areas of the PVN and SON, but the staining level was much less than in the SCN.

Strong staining was found in cells of the thalamic nuclei (thalamic atlas of Caviness and Frost, 1980), including the dorsal lateral geniculate (Fig. 10A) and ventrobasal complex. These areas all showed relatively little staining in the adult, while cells of the intergeniculate leaflet did show immunoreactivity in the adult (Fig. 10C). The thalamic gelatinosa nucleus was also immunoreactive, both in the neonate and adult. In both adult and neonatal rats, scattered neurons were found throughout the hippocampus in regions where interneurons are normally located.

$V G F$ immunocytochemical controls for specificity. The VGF immunostaining of the SCN and the magnocellular neurons of the PVN and SON was not blocked by addition of $E$. coli bacterial lysate to either of the 2 antisera against VGF. Similarly, the addition of purified $\beta$-gal did not block the immunostaining, indicating that the critical antigenic staining sites were not related to the $\beta$-gal link used to detect the VGF gene sequence.

Addition of VGF protein isolated by gel purification to the antisera blocked positive immunostaining in the brain (Levi et al., unpublished observations). Antisera made against the product of an unrelated cDNA fusion of lambda cro to $\beta$-gal showed no immunoreactivity in the SCN (Fig. $3 D$ ), PVN, or SON. That this antiserum was used at a concentration sufficient to generate positive immunostaining was indicated by the unexpected bilateral immunostaining of a small number of neurons in the dorsal lateral hypothalamus (Fig. $3 E$ ).

$N G F-R$ immunostaining. NGF-R immunostaining was found in the ventrolateral part of the SCN (Fig. $11 A$; see also Sofroniew et al., 1989). In rats not treated with colchicine, there appeared to be little general overlap between the area of the SCN immunoreactive for VGF and that immunoreactive for NGF-R. Unlike NGF-R control staining in the medial septum, the immunoreactivity in the SCN appeared to be in the neuropil rather than in perikarya. The cells immunoreactive for NGF-R in the medial septum did not show immunoreactivity for VGF. Immediately dorsolateral to the SON, immunoreactivity for NGF$\mathrm{R}$ was detected in large perikarya and proximal dendrites of large neurons which were loosely scattered in a dorsolateral direction (Fig. $11 \mathrm{~B}$ ); VGF immunoreactivity was not detected in these cells. Peroxidase reactivity was seen in the ventral part of the SON (Fig. 11B); the peroxidase reaction product did not appear to be staining neurons specifically, but rather cells with a glial appearance. Whether astrocytes in the ventral lamina 

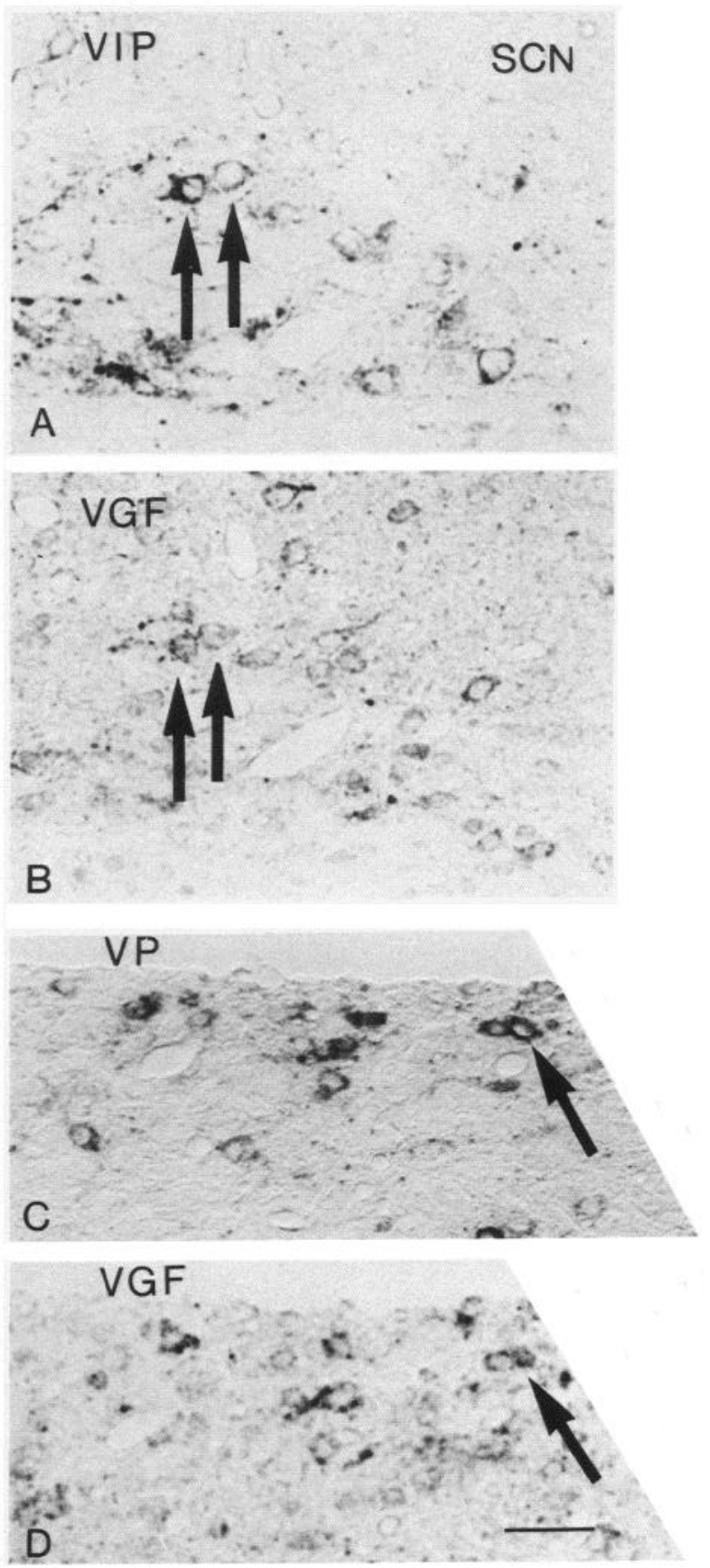
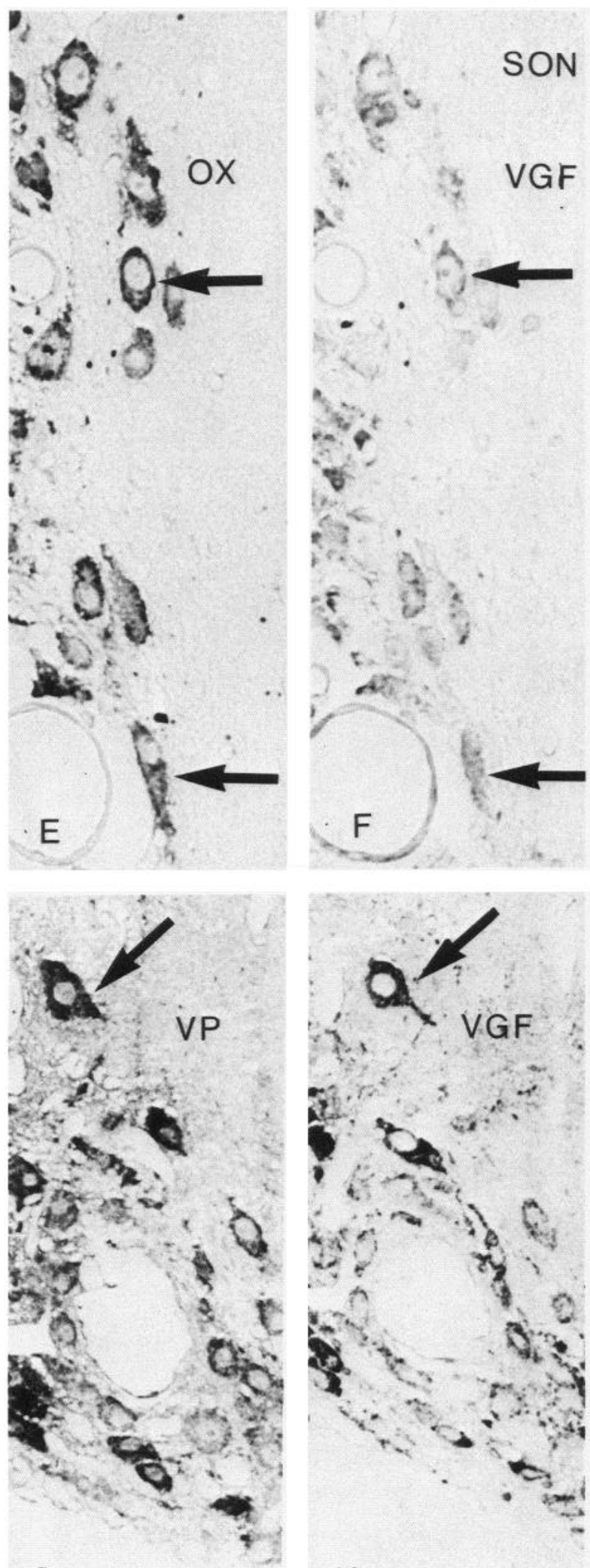

G

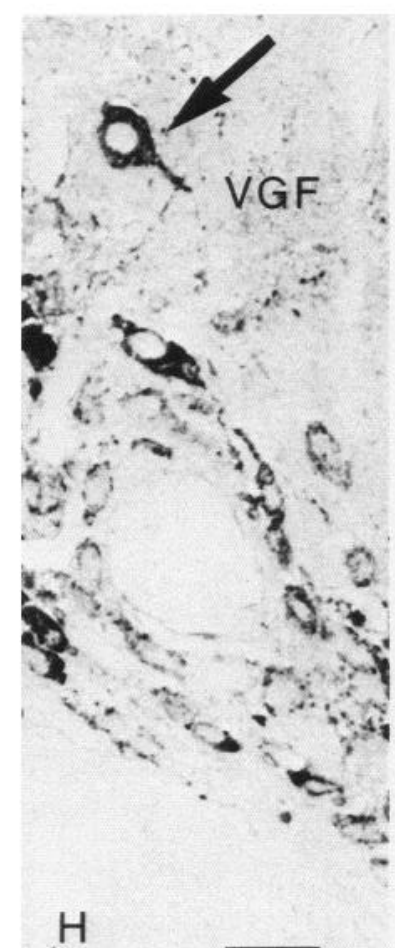

Figure 9. Co-localization of VIP or vasopressin with VGF in SCN. Two cells (arrows) in $1 \mu \mathrm{m}$ paraffin section are stained with antisera against vasoactive intestinal polypeptide $(A ; V I P)$ and are also immunoreactive for VGF in the SCN of colchicine treated rats $(B)$. Cells $($ arrow) containing immunoreactivity indicative of vasopressin-neurophysin $(C ; V P)$ and also stained with VGF antisera $(D)$. Scale bar, $35 \mu \mathrm{m}$. $E-H$, Co-localization of oxytocin or vasopressin with VGF. Cells stained with antisera against oxytocin $(E ; O X)$ also stained with antisera against VGF $(F ;$ arrows). Similarly, cells strongly stained with vasopressin $(G)$ are also immunoreactive with antisera against VGF $(H ;$ arrow). Scale bar, $32 \mu$ m. 

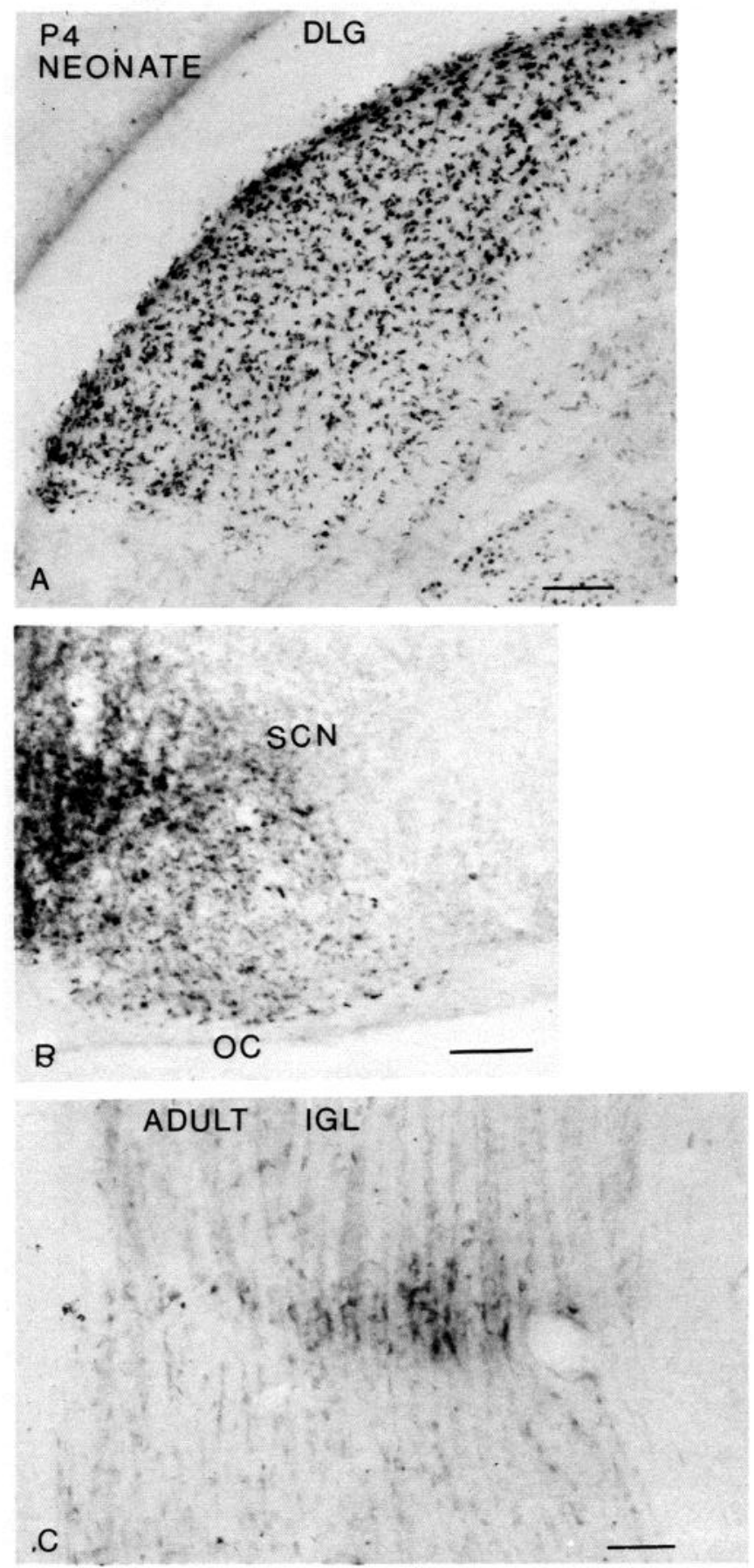

Figure 10. Neonatal expression of VGF immunoreactivity $4 \mathrm{~d}(\mathrm{P} 4)$ after birth in retinal target regions. $A$, Cell bodies in the dorsal lateral geniculate are strongly stained with VGF antisera. Scale bar, $50 \mu \mathrm{m} . B$, In the $\mathrm{SCN}$, immunoreactive cells are found in both the dorsomedial area, as well as in the ventrolateral region on the nucleus. Scale bar, 60 $\mu \mathrm{m}$. $C$, Immunoreactivity in the adult rat in the thalamic intergeniculate leaflet $(I G L)$, a projection area to the SCN. Scale bar, $40 \mu \mathrm{m}$.

may be immunoreactive will require further study. NGF-R immunostaining was not detected in the PVN.

\section{Discussion}

In the present study, several lines of evidence indicate that the antigen localized in the hypothalamus is the translated product of the VGF gene. First, 2 different antisera were made against different amino acid sequences coded by the open reading frame of the VGF cDNA. Each of them independently stained the same cells in the SCN. With colchicine treatment, both also stained the same magnocellular neurons in the PVN and SON, as well as a few adjacent neurons in the arcuate nucleus. That the staining was not related to antibodies that cross-reacted with $\beta$-gal was shown by the finding that incubation of $\beta$-gal with each of the antisera, and incubation of lysed bacterial protein including $\beta$-gal did not inhibit the immunostaining. Use of an antiserum against a different gene product fused with $\beta$-gal did not stain cells of either the SCN, PVN, or SON. Furthermore, VGF gene fragments from a PC12 cell library hybridized with an equivalent species from a brain cDNA library. Finally, Northern blots demonstrate mRNAs of similar molecular weights in both PC1 2 cells and in brain. The fact that colchicine increases immunoreactivity in neuronal somata argues that the immunoreactive protein is one synthesized in the neurons, rather than one taken up from the surrounding cellular microenvironment.

\section{Restricted expression and co-localization}

In addition to VGF immunoreactivity, other substances have been found in both the SCN and magnocellular neurons in the PVN and SON. For instance, vasopressin and its related carrier protein neurophysin are found in the dorsomedial SCN (Sofroniew and Weindl, 1978, 1980; Buijs, 1980; van den Pol and Tsujimoto, 1985), as well as in magnocellular neurons projecting to the neurohypophysis. Unlike vasopressin and neurophysin antisera, which both stain the magnocellular neurons more strongly than the small cells in the SCN, both VGF antibodies stain the SCN cell bodies more intensely than the cell bodies of neurons in the SON and PVN. This was true regardless of the immunostaining procedure used (HRP-labeled secondary IgG, ABC, PAP, silver-intensified peroxidase, or silver-intensified gold), suggesting that stronger reaction product in the $\mathrm{SCN}$ was due to a greater concentration of VGF antigen in the cells of the SCN than in the cells of the PVN or SON, rather than a histochemical artifact (Bigbee et al., 1977).

Why cells of the SCN would stain more darkly in the absence of colchicine than the magnocellular neurons of the PVN and SON may be due to a greater rate of synthesis in the SCN than other areas. This receives additional support from the observation that $\mathrm{SCN}$ axons also stain more intensely than PVN or SON axons. This is a little surprising since the SCN cells in general, and VGF immunoreactive neurons in addition, give little evidence of synthetic organelles compared with the metabolically more active magnocellular neurons. An alternative explanation is that the protein is transported out of the cell body at a slower rate in the $\mathrm{SCN}$, leading to a greater concentration of antigen in SCN perikarya. A final possibility is that the rate of degradation or posttranslational alterations in the VGF protein may be different or slower in the $\mathrm{SCN}$, leading to a greater accumulation of the immunodetectable antigen.

The VGF protein appears to be the first antigen of restricted neuronal expression found in the SCN that labels both ventrolateral and dorsomedial cell groups (in colchicine-treated rats). Previously, neuroactive peptides and synthesizing enzymes have been generally restricted to either the dorsomedial area (vasopressin, neurophysin, aromatic amino acid decarboxylase: Sofroniew and Weindl, 1978; Buijs, 1980; Jaeger et al., 1983) or the ventrolateral area (vasoactive intestinal polypeptide, peptide isoleucine, gastrin-releasing peptide: Card et al., 1981, 1988; 

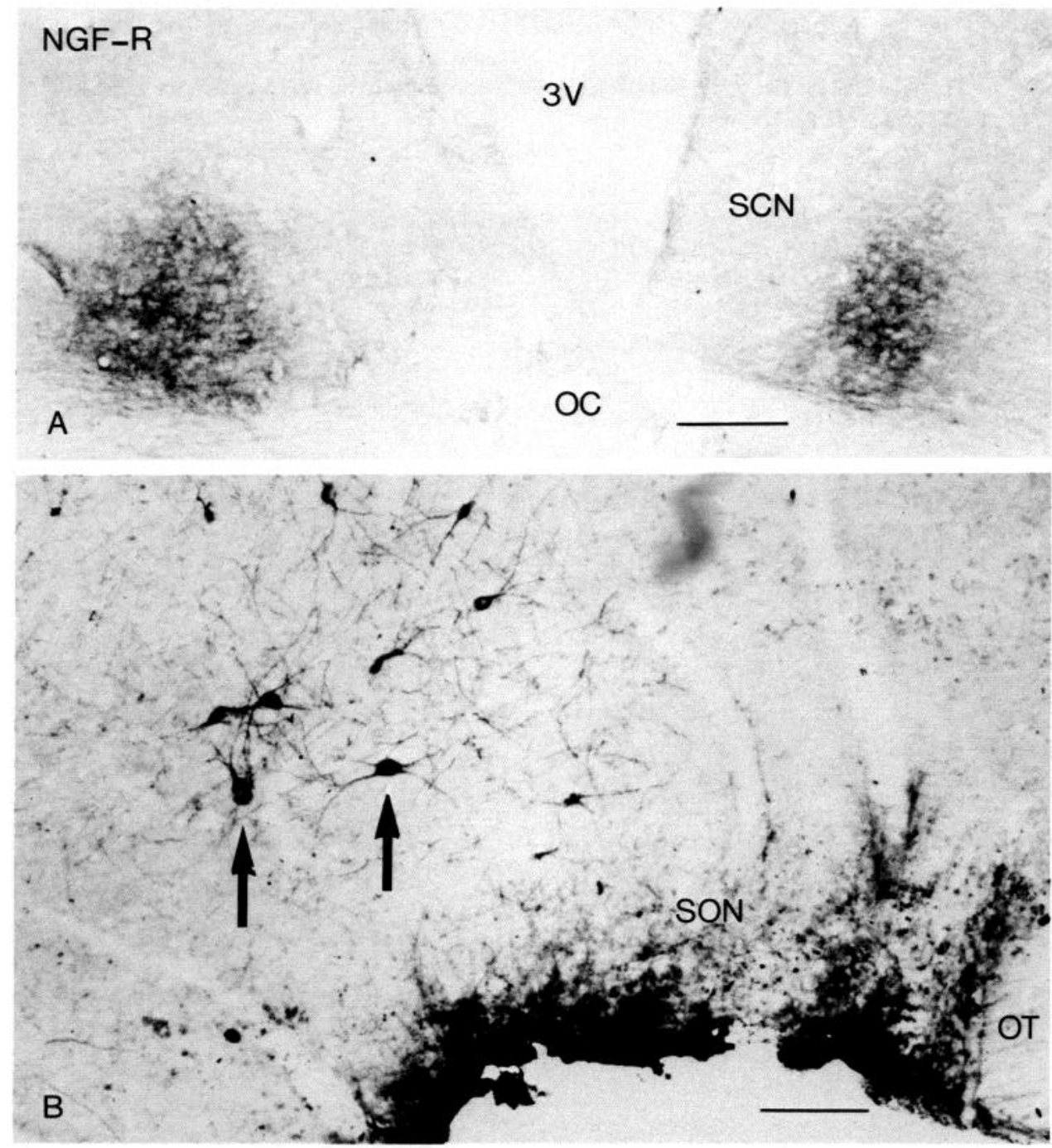

Figure 11. NGF-receptor immunoreactivity in hypothalamus. $A$, Strong NGF-R immunoreactivity was found at the lateral aspect of both SCN. Scale bar, $150 \mu \mathrm{m}$. Unlike the cellular localization of immunoreactivity dorsolateral to the SON in $B$, that in the SCN appears more diffuse, suggestive of axonal localization. $B$, Large intensely stained immunoreactive cells with perikaryal and dendritic labeling are seen (arrows) dorsolateral to the SON. A diffuse reaction product is also seen in the ventral part of SON; this reaction product does not seem to be associated with the large magnocellular neurons of the SON. Scale bar, $90 \mu \mathrm{m}$. $3 \mathrm{~V}$, third ventricle; $O T$, optic tract; $O C$, optic chiasm.
Roth et al., 1982; van den Pol and Tsujimoto, 1985; van den Pol and Gorcs, 1986). Analysis of cell size and packing density also suggests 2 major subgroups within the SCN (van den Pol, 1980). Vasopressin and its associated neurophysin are found in restricted regions of the $\mathrm{SCN}$, predominantly in the dorsomedial area. This is the same region where the strongest VGF immunostaining is found in the absence of colchicine. To exclude the possibility that the VGF gene might be directly related to the vasopressin gene, Brattleboro rats were studied. Although vasopressin and its associated neurophysin cannot be found in these rats, the VGF protein immunoreactivity appeared normal with both antisera used. Further evidence that the VGF gene is independent of the vasopressin gene is evidenced by the finding of VGF immunoreactivity in neurons of the hypothalamus, such as in the arcuate nucleus, where vasopressin is not found.

The known projection sites of SCN efferents (Stephan et al., 1981; Watts and Swanson, 1987; Watts et al., 1987), which we examined from cells in both the ventrolateral and dorsomedial regions of the nucleus, contained axons with VGF immunoreactivity. While we have not shown that these axons necessarily originate from the $\mathrm{SCN}$ rather than some other area containing VGF-immunoreactive perikarya, a SCN origin of at least some of them is probable.

\section{Expression of $V G F$ and relation to $N G F-R$}

The VGF cDNA used to express the proteins against which the antisera in the present study were made was initially detected by the 50 -fold increase of complementary mRNA $5 \mathrm{hr}$ after induction by the addition of NGF to PC12 cells. This led to the speculation that the VGF gene may play a critical role as an intermediary between NGF stimulation and a host of developmental sequelae that follow. Recent studies have shown that NGF may play an important role in the ongoing maintenance of some neurons of the CNS, particularly in the medial septum (Gnahn et al., 1983; Hefti et al., 1986). NGF-R can be detected immunocytochemically in these areas, as well as in PC12 cells. In the present study, we did not find NGF-R immunostaining on SCN perikarya in the same area where we found VGF immunoreactivity. We did, however, find immunoreactivity suggestive of an axonal localization in neuropil of the SCN, in an area generally restricted to the ventrolateral SCN. This is in the same region that receives input from the retina (Hendrickson et al., 1972; Moore and Lenn, 1972) and from the intergeniculate leaflet (Ribak and Peters, 1975; Card and Moore, 1982), suggesting that a putative source of fibers containing NGF-R may be one of these areas. Thus, in the CNS while there appears to 
be a correlation of expression of NGF-R and VGF in the area of SCN and SON, there does not appear to be a cellular correlation, in that cell bodies of the SCN do not express sufficient NGF-R to detect with immunostaining. Furthermore, regions of the PVN that contain VGF immunoreactivity do not show NGF-R immunostaining. Of related interest is that the intergeniculate leaflet in colchicine-treated rats does contain perikarya immunoreactive for VGF, but not for NGF-R. A parallel examination of the medial septum and lateral hypothalamus demonstrated neurons which express strong immunoreactivity for NGF-R, but not for VGF. Taken together these data do not support the hypothesis that the VGF protein is a necessary factor mediating the physiological roles of the NGF in the adult brain. The finding of NGF-R in the ventrolateral region of SCN leads to the interesting speculation that some cells of the SCN may synthesize and secrete NGF.

Thus, NGF may augment the expression of VGF in $\mathrm{PC} 12$ cells, but may not be crucial for its expression in the hypothalamus. On the other hand, the VGF protein may have a function related to early physiological events in developing neurons, as evidenced by the strong expression of VGF in the SCN of males and females by postnatal day 4 , and probably earlier, given the strong staining seen at day 4 . Like VGF, NGF receptor immunoreactivity decreases with age in a number of different areas of the brain, including the lateral geniculate nucleus (Yan and Johnson, 1988).

\section{$V G F$ function}

The function of VGF is unknown at this point. The speculation that the VGF gene may code for a substance that may be released from axon endings merits further investigation: first, the VGF immunoreaction product is present in axonal terminals at synaptic boutons and in axon terminals in the neurohypophysis. If the protein or a cleavage product of it is released, we might expect to locate it ultrastructurally in vesicles. The preembedding peroxidase ultrastructural immunostaining done in the present study showed a cytoplasmic localization of peroxidase reaction product. That this is not necessarily demonstrative of the location of the antigen in the live neuron is indicated by similar cytoplasmic (and artifactual) immunolocalization of vesicular neuroactive peptides such as vasopressin, oxytocin, ACTH, and LHRH (see discussion in van den Pol, 1985) with similar methodologies. Preliminary studies based on postembedding immunostaining were not successful. Immunoreactivity was also found in some large dendrites of magnocellular neurons; unusual dendrites which stain intensely with oxytocin, vasopressin, and neurophysin, and contain large numbers of large dense-core secretory vesicles have been described in the same areas (Sofroniew and Glasmann, 1981; Armstrong et al., 1982), and VGF immunoreactivity here is consistent with the possibility that VGF may be associated with secretory vesicles.

Second, colchicine, which blocks axonal transport, results in a strong increase in the antigen in the neuronal perikarya of the SCN, SON, and PVN, as well as in other regions of the brain, suggesting that the VGF protein, or part of it, is transported to axon terminals. Third, additional unpublished experiments (Possenti et al.) indicate that the stimulation of PC12 cells with $\mathrm{K}^{+}$, the calcium ionophore $\mathrm{A} 23187$, or $\alpha$-latrotoxin causes release of a substance from PC1 2 cells which can be detected with antibodies against the VGF protein. If a component of VGF is released, it may well be a posttranslational cleavage product.
That the VGF protein may be cleaved into smaller peptides is not inconsistent with the large number of arginine-arginine and arginine-lysine sequences that would be likely points of proteolytic cleavage.

The VGF protein does not appear to be directly related to other known peptides or proteins, as suggested by the lack of cDNA sequence homologies with sequences in the National Sequence Data Bank (Levi et al., 1985) and by the lack of amino acid homologs from the NBRF protein sequence bank (1988). Whether the partial similarity between VGF and the Drosophila biological clock protein per indicates some real biological similarity of the 2 proteins or is simply due to chance similarity merits further experimental consideration.

\section{References}

Anderson, D. J., and R. Axel (1985) Molecular probes for the development and plasticity of neural crest derivatives. Cell 42: 649-662.

Armstrong, W. E., S. Warach, G. I. Hatton, and T. H. McNeill (1980) Subnuclei in the rat paraventricular nucleus: A cytoarchitectural, HRP, and immunocytochemical analysis. Neuroscience 206: 317-345.

Armstrong, W. E., J. Scholer, and T. H. McNeill (1982) Immunocytochemical, Golgi and electron microscopic characterization of putative dendrites in the ventral glial lamina of the rat supraoptic nucleus. Neuroscience 7: 679-694.

Ayer-LeLievre, C., L. Olson, T. Ebendal, A. Seiger, and H. Persson (1988) Expression of the B-nerve growth factor gene in hippocampal neurons. Science 240: 1339-1341.

Batchelor, P. E., S. N. Blaker, D. M. Armstrong, and F. H. Gage (1987) Nerve growth factor receptor and choline acetyltransferase colocalization within the rat forebrain: Response to fimbria-fornix transection. Soc. Neurosci. Abstr. 13: 1393.

Bigbee, J. W., J. C. Kosek, and L. F. Eng (1977) Effects of primary antiserum dilution on staining of "antigen-rich" tissues with the peroxidase antiperoxidase technique. J. Histochem. Cytochem. 25: 443447.

Buijs, R. M. (1980) Vasopressin and Oxytocin Innervation of the Rat Brain. Doctoral Dissertation, Netherlands Institute for Brain Research, Amsterdam.

Burstcin, D. E., and L. A. Greenc (1978) Evidence for RNA synthesisdependent and independent pathways in stimulation of neurite outgrowth factor. Proc. Natl. Acad. Sci. USA 75: 6059-6063.

Card, J. P., and R. Y. Moore (1982) Ventral lateral geniculate nucleus efferents to the rat suprachiasmatic nucleus exhibit avian pancreatic polypeptide-like immunoreactivity. J. Comp. Neurol. 206: 390-396.

Card, J. P., N. Brecha, H. J. Karten, and R. Y. Moore (1981) Immunocytochemical localization of vasoactive intestinal polypeptidecontaining cells and processes in the suprachiasmatic nucleus of the rat: Light and electron microscopic analysis. J. Neurosci. 1: 12891303.

Card, J. P., S. Fitzpatrick-McElligott, I. Gozes, and F. Baldino (1988) Localization of vasopressin-, vasoactive intestinal polypeptide-, peptide isoleucine- and somatostatin-mRNA in rat suprachiasmatic nucleus. Cell Tissue Res. 252: 307-315.

Caviness, V. S., and D. O. Frost (1980) Tangential organization of thalamic projections to the neocortex in the mouse. J. Comp. Neurol. 194: 335-367.

Chandler, C. E., L. M. Parsons, M. Hosang, and E. M. Shooter (1984) A monoclonal antibody modulates the interaction of nerve growth factor with PC12 cells. J. Biol. Chem. 259: 6882-6889.

Citri, Y., H. V. Colot, A. C. Jacquier, Q. Yu, J. C. Hall, D. Baltimore, and M. Rosbash (1987) A family of unusually spliced biologically active transcripts encoded by a Drosophila clock gene. Nature 326 : $42-47$.

Cotmore, S. F., and P. Tattersall (1986) Organization of nonstructural genes of the autonomous parvovirus minute virus of mice. J. Virol. 58: 724-732.

Ericson, H., T. Watanabe, and C. Kohler (1987) Morphological analysis of the tuberomammillary nucleus in the rat brain: Delineation of subgroups with antibody against L-histidine decarboxylase as a marker. J. Comp. Neurol. 263: 1-24.

Gage, F., D. M. Armstrong, L. R. Williams, and S. Varon (1988) 
Morphological response of axotomized septal neurons to nerve growth factor. J. Comp. Neurol. 269: 147-155.

Gallyas, F., and I. Merchenthaler (1988) Copper- $\mathrm{H}_{2} \mathrm{O}_{2}$ oxidation strikingly improves silver intensification of the nickel-diaminobenzidine (Ni-DAB) end-product of the peroxidase reaction. J. Histochem. Cytochem. 36: 807-810.

Gnahn, H., F. Hefti, R. Heumann, M. E. Schwab, and H. Thoenen (1983) NGF-mediated increase of choline acetyltransferase (ChAT) in the neonatal rat forebrain: Evidence for a physiological role of NGF in the brain? Dev. Brain Res. 9: 45-52.

Greene, L. A., and A. S. Tischler (1976) Establishment of a noradrenergic clonal line of rat adrenal pheochromocytoma cells which respond to nerve growth factor. Proc. Natl. Acad. Sci. USA 73: 24242428.

Groos, G., and J. Hendriks (1982) Circadian rhythms in electrical discharge of rat suprachiasmatic neurones recorded in vitro. Neurosci. Lett. 34: 283-288.

Hefti, F., J. Hartikka, A. Salvatierra, W. J. Weiner, and D. C. Mash (1986) Localization of nerve growth factor receptors in cholinergic neurons of the human basal forebrain. Neurosci. Lett. 69: 37-41.

Hendrickson, A. E., N. Wagoner, and W. M. Cowan (1972) An autoradiographic and electron microscopic study of retino-hypothalamic connections. Z. Zellforsch. 135: 1-26.

Honegger, P., and D. Lenoir (1982) Nerve growth factor (NGF) stimulation of cholinergic telencephalic neurons in aggregating cell cultures. Dev. Brain Res. 3: 229-238.

Hsu, S., L. Raine, and H. Fanger (1981) Use of avidin-biotin-peroxidase complex $(\mathrm{ABC})$ in immunoperoxidase techniques: $\mathrm{A}$ comparison between $A B C$ and unlabeled antibody (PAP) procedures. J. Histochem. Cytochem. 29: 577-580.

Inouye, S. T., and H. Kawamura (1979) Persistence of circadian rhythmicity in a mammalian hypothalamic "island" containing the suprachiasmatic nucleus. Proc. Natl. Acad. Sci. USA 76: 5962-5966.

Jackson, F. R., T. A. Bargiello, S. Yun, and M. W. Young (1986) Product of PER locus of Drosophila shares homology with proteoglycans. Nature 320: 185-188.

Jaeger, C. B., V. R. Albert, T. H. Joh, and D. J. Reis (1983) Aromatic L-amino acid decarboxylase in the rat brain: Coexistence with vasopressin in small neurons of the suprachiasmatic nucleus. Brain Res. 276: 362-366.

Leonard, D. G. B., E. B. Ziff, and L. A. Greene (1987) Identification and characterization of mRNAs regulated by nerve growth factor in PC12 cells. Mol. Cell Biol. 7: 3156-3167.

Levi, A., J. D. Eldridge, and B. M. Paterson (1985) Molecular cloning of a gene sequence regulated by nerve growth factor. Science 229 : 393-395.

Levi-Montalcini, R., and P. U. Angeletti (1968) The nerve growth factor. Physiol. Rev. 48: 534-569.

Majzoub, J. A., J. Carrazana, J. S. Shulman, K. J. Baker, and R. L. Emanuel (1987) Defective regulation of vasopressin gene expression in Brattleboro rats. Am. J. Physiol. 252: E637-642.

Moore, R. Y., and V. B. Eichler (1972) Loss of circadian adrenal corticosterone rhythm following suprachiasmatic nucleus lesions. Brain Res. 42: 201-206.

Moore, R. Y., and N. J. Lenn (1972) A retinohypothalamic projection in the rat. J. Comp. Neurol. 146: 1-14.

Raivich, G. and G. W. Kreutzberg (1987) The localization and distribution of high affinity $\beta$-nerve growth factor binding sites in the central nervous system of the adult rat. A light microscopic autoradiographic study using [125I] $\beta$-nerve growth factor. Neuroscience 20 23-36.

Ribak, C. E., and A. Peters (1975) An autoradiographic study of the projections from the lateral geniculate body of the rat. Brain Res. 92: 241-268.

Roth, K. A., E. Weber, and J. D. Barchas (1982) Distribution of gastrin releasing peptide-bombesin-like immunostaining in rat brain. Brain Res. 251: 277-282.

Schmale, H., and D. Richter (1984) Single base deletion in the vasopressin gene is the cause of diabetes insipidus in Brattleboro rats. Nature 308: 705-709.

Schwartz, W. J., and H. Gainer (1977) Suprachiasmatic nucleus: Use of 14-C labeled deoxyglucose uptake as a functional marker. Science 197: 1089-1091.

Sofroniew, M. V., and W. Glasmann (1981) Golgi-like immunoperoxidase staining of hypothalamic magnocellular neurons that contain vasopressin, oxytocin or neurophysin in the rat. Neuroscience $6: 619$ 643.

Sofroniew, M. V., and A. Weindl (1978) Projections from the parvocellular vasopressin- and neurophysin-containing neurons of the suprachiasmatic nucleus. Am. J. Anat. 153: 391-430.

Sofroniew, M. V., and A. Weindl (1980) Identification of parvocellular vasopressin and neurophysin neurons in the suprachiasmatic nucleus of a variety of mammals including primates. J. Comp. Neurol. 193: 659-675.

Sofroniew, M. V., O. Isacson, and T. S. O'Brien (1989) Nerve growth factor receptor in the rat suprachiasmatic nucleus. Brain Res. 476: 358-362.

Stephan, F. K., and I. Zucker (1972) Circadian rhythms in drinking behavior locomotor activity of rats are eliminated by hypothalamic lesions. Proc. Natl. Acad. Sci. USA 69: 1583-1586.

Stephan, F. K., K. J. Berkley, and R. L. Moss (1981) Efferent connections of the rat suprachiasmatic nucleus. Neuroscience 6: 26252641.

Sternberger, L. A. (1986) Immunocytochemistry, Wiley, New York.

Swanson, L. W., and S. McKellar (1979) The distribution of oxytocinand neurophysin-stained fibers in the spinal cord of the rat and monkey. J. Comp. Neurol. 188: 87-106.

Swanson, L. W., and P. E. Sawchenko (1983) Hypothalamic integration: Organization of the paraventricular and supraoptic nuclei. Annu. Rev. Neurosci. 6: 269-324.

van den Pol, A. N. (1980) The hypothalamic suprachiasmatic nucleus of rat: Intrinsic anatomy. J. Comp. Neurol. 191: 661-702.

van den Pol, A. N. (1981) Amino acid incorporation in medial hypothalamic nuclei: Circadian, perikarya and neuropil variations. Am. J. Physiol. 240: R16-R22.

van den Pol, A. N. (1985) Silver-intensified gold and peroxidase as dual ultrastructural immunolabels for pre- and postsynaptic neurotransmitters. Science 228: 332-335.

van den Pol, A. N. (1986) Gamma-aminobutyrate, gastrin releasing peptide, serotonin, somatostatin, and vasopressin: Ultrastructural immunocytochemical localization in presynaptic axons in the suprachiasmatic nucleus. Neuroscience 17: 643-659.

van den Pol, A. N., and T. Gorcs (1986) Synaptic relationships between neurons containing vasopressin, GRP, VIP, and glutamate decarboxylase immunoreactivity in the suprachiasmatic nucleus: Dual ultrastructural immunocytochemistry with gold substituted silver peroxidase. J. Comp. Neurol. 252: 507-521.

van den Pol, A. N., and T. Powley (1979) A fine-grained anatomical analysis of the role of the rat suprachiasmatic nucleus in circadian rhythms of feeding and drinking. Brain Res. 160: 307-326.

van den Pol, A. N., and K. Tsujimoto (1985) Neurotransmitters of the hypothalamic suprachiasmatic nucleus: Immunocytochemical analysis of 25 neuronal antigens. Neuroscience 15: 1049-1086.

van den Pol, A. N., C. Decavel, A. Levi, and B. Paterson (1988) Suprachiasmatic nucleus expression of gene product induced by NGF in $\mathrm{PC} 12$ cells. Soc. Neurosci. Abstr. 14: 1180.

Watts, A. G., and L. W. Swanson (1987) Efferent projections of the suprachiasmatic nucleus: II. Studies using retrograde transport of fuorescent dyes and simultaneous peptide immunohistochemistry in the rat. J. Comp. Neurol. 258: 230-252.

Watts, A. G.,, L. W. Swanson, and G. Sanchez-Watts (1987) Efferent projections of the suprachiasmatic nucleus: 1 . Studies using anterograde transport of Phaseolus vulgaris leucoagglutinin in the rat. J. Comp. Neurol. 258: 204-229.

Williams, L. R., S. Varon, G. M. Peterson, K. Wictorin, W. Fischer, A. Bjorklund, and F. H. Gage (1986) Continuous infusion of nerve growth factor prevents basal forebrain neuronal death after fimbria fornix transection. Proc. Natl. Acad. Sci. USA 83: 9231-9235.

Yan, Q., and E. M. Johnson (1988) An immunohistochemical study of the nerve growth factor receptor in developing rats. J. Neurosci. 8: 3481-3498. 